\title{
Friends or Foes-Microbial Interactions in Nature
}

\author{
Nancy Weiland-Bräuer
}

check for

updates

Citation: Weiland-Bräuer, N. Friends or Foes-Microbial Interactions in

Nature. Biology 2021, 10, 496.

https://doi.org/10.3390/

biology10060496

Academic Editor: Katsutoshi Hori

Received: 11 May 2021

Accepted: 31 May 2021

Published: 2 June 2021

Publisher's Note: MDPI stays neutral with regard to jurisdictional claims in published maps and institutional affiliations.

Copyright: (C) 2021 by the author. Licensee MDPI, Basel, Switzerland. This article is an open access article distributed under the terms and conditions of the Creative Commons Attribution (CC BY) license (https:/ / creativecommons.org/licenses/by/ $4.0 /)$.
Institute of General Microbiology, Kiel University, 24118 Kiel, Germany; nweiland@ifam.uni-kiel.de; Tel.: +49-431-880-1649

Simple Summary: Microorganisms like bacteria, archaea, fungi, microalgae, and viruses mostly form complex interactive networks within the ecosystem rather than existing as single planktonic cells. Interactions among microorganisms occur between the same species, with different species, or even among entirely different genera, families, or even domains. These interactions occur after environmental sensing, followed by converting those signals to molecular and genetic information, including many mechanisms and classes of molecules. Comprehensive studies on microbial interactions disclose key strategies of microbes to colonize and establish in a variety of different environments. Knowledge of the mechanisms involved in the microbial interactions is essential to understand the ecological impact of microbes and the development of dysbioses. It might be the key to exploit strategies and specific agents against different facing challenges, such as chronic and infectious diseases, hunger crisis, pollution, and sustainability.

Abstract: Microorganisms are present in nearly every niche on Earth and mainly do not exist solely but form communities of single or mixed species. Within such microbial populations and between the microbes and a eukaryotic host, various microbial interactions take place in an ever-changing environment. Those microbial interactions are crucial for a successful establishment and maintenance of a microbial population. The basic unit of interaction is the gene expression of each organism in this community in response to biotic or abiotic stimuli. Differential gene expression is responsible for producing exchangeable molecules involved in the interactions, ultimately leading to community behavior. Cooperative and competitive interactions within bacterial communities and between the associated bacteria and the host are the focus of this review, emphasizing microbial cell-cell communication (quorum sensing). Further, metagenomics is discussed as a helpful tool to analyze the complex genomic information of microbial communities and the functional role of different microbes within a community and to identify novel biomolecules for biotechnological applications.

Keywords: microorganisms; interaction; symbiosis; metaorganism; metagenomics; biofilms; quorum sensing; quorum quenching

\section{Introduction-Microbial Interactions at a Glance}

Microorganisms, or short microbes, are speciesism of microscopic scale, including the highly diverse group of unicellular organisms belonging to the three domains of life, comprising bacteria, archaea, protozoa, microalgae, fungi, and viruses. Microorganisms are present in nearly every niche on Earth and their global distribution is striking, ranging from the human gut to deep subsurface in terrestrial and marine environments and the upper atmosphere [1]. Prokaryotes (bacteria, archaea) and viruses form the majority of microorganisms and, consequently, represent the review's focus. Exemplarily, bacteria reach abundances of $1 \times 10^{8}$ cells $/ g$ and viruses even of $5 \times 10^{9}$ particles/g in dry soil; in oceans, bacteria achieve densities of $5 \times 10^{5}$ cells $/ \mathrm{mL}$ and viral particles $1 \times 10^{11}$ viruses $/ \mathrm{mL}$ [2] . Microbes mainly do not exist solely but form communities of single or mixed species [3]. Within such microbial populations, and between the microbes and a eukaryotic host or the environment, a huge variety of microbial interactions occur, ranging from bacteria-bacteria, bacteria-fungus, bacteria-virus, to bacteria-host (plant, animal) interactions [4]. 
Those microbial interactions are crucial for successfully establishing and maintaining a microbial population in various environments and on various hosts [5]. The many years of coevolution of the different species led to interdependent adaptation and specialization and resulted in various symbiotic relationships facilitating commensal, mutualistic, and parasitic interactions [5] (as illustrated in Table 1). Mutualism describes a win-win situation for both partners, such as for Rhizobium spp., which colonizes the plant's roots to fix nitrogen in exchange for nutrients [6]. Moreover, human gut bacteria synthesize the essential vitamin $\mathrm{K}$ in the lower gastrointestinal tract to exchange carbon sources [7]. Relationships in which only one partner benefits, but the other is not affected, is defined as commensalism, in contrast to parasitism, in which the benefiting partner harms the other partner. The evidence is increasing that commensal bacteria, which reside in the human gut and airways, profoundly affect the regulation of immunophysiological functions, including metabolism, ontogeny, and pathogen defense [8,9]. Contrarily, parasitic bacteria, better known as pathogens, harm their host in various ways, such as invading tissues, producing toxins, or causing direct damage to host cells. Pathogens causing diseases are well studied and broadly recognized by the public, such as Bacillus anthracis, the cause of anthrax [10]; Borrelia spp., the cause of Lyme disease [11]; Campylobacter jejuni, a cause of gastroenteritis [12], and Haemophilus influenza, an agent of bacterial meningitis and respiratory tract infections [13]. The list of parasitic interactions, particularly focusing on human diseases, could be expanded indefinitely; however, mechanistic understanding of commensal and mutualistic interactions, especially between prokaryotes, lags [14]. Microbial interactions occur through the transfer of molecular and genetic information, including the exchange of secondary metabolites, signaling molecules, cellular transduction signals, siderophores, or genetic elements [5]. The basic unit of the interaction is the gene expression of each organism in response to biotic or abiotic stimuli, responsible for producing exchangeable molecules involved in these interactions [15].

Table 1. Types of microbial interactions adapted from [16].

\begin{tabular}{|c|c|c|c|c|}
\hline Interaction & Characteristic & Species A & Species B & Example \\
\hline Mutualism & $\begin{array}{c}\text { Symbiosis needed for } \\
\text { survival in a specific } \\
\text { habitat }\end{array}$ & Benefits & Benefits & Root nodules [6] \\
\hline Synergism & $\begin{array}{l}\text { Another improves the } \\
\text { growth of one partner }\end{array}$ & Benefits & Benefits & $\begin{array}{c}\text { Crossfeeding of acetate between } \\
\text { bacteria [17] }\end{array}$ \\
\hline Commensalism & $\begin{array}{l}\text { One partner benefits } \\
\text { and the other is not } \\
\text { harmed nor improved }\end{array}$ & Benefits & Not affected & $\begin{array}{l}\text { Nitrification with Nitrosomonas } \\
\text { and Nitrobacter [18] }\end{array}$ \\
\hline Parasitism & Host is compromised & Benefits & Harmed & $\begin{array}{l}\text { Bdellovibrio sp. and BALO require } \\
\text { Gram-negative bacterium for } \\
\text { growth [19] }\end{array}$ \\
\hline Competition & $\begin{array}{l}\text { Rivalry for space and } \\
\text { nutrients }\end{array}$ & Harmed & Harmed & $\begin{array}{l}\text { Soil bacteria compete with fungi } \\
\text { for nutrients [20] }\end{array}$ \\
\hline Antagonism & $\begin{array}{l}\text { Product(s) of one } \\
\text { partner impact another }\end{array}$ & $\begin{array}{l}\text { Not affected or } \\
\text { benefits }\end{array}$ & Harmed & Production of antibiotics [21] \\
\hline
\end{tabular}

In the following, examples of microorganism-microorganism and microorganismhost interactions are presented in more detail to demonstrate the variety and diversity of microbial interactions in different habitats.

\section{Microbial Community Interactions}

Microbes respond to their chemical environment and interact with other microbes in their vicinity [22]. The nature and significance of interactions depend on the abundance and types of microorganisms present, which possess different sensory systems [23]. Cell- 
cell interactions can cause cooperative effects, where one or more individuals benefit, or competition between microbes occurs with an adverse effect on one or more partners. Microbes are not limited to a single type of interaction, and their response is transient and influenced by the chemical and/or physical environment, resulting in a highly complex microbial community [5].

\subsection{Fungal Interactions}

Fungi inhabit a broad range of environmental niches and account for at least $25 \%$ of the global biomass. In their natural environment, fungi interact with other microorganisms, such as other fungi and bacteria (as illustrated in Figure 1). Both intra- and interspecific fungal interactions are mediated upon contact and/or signaling molecules leading to, e.g., mating, alterations in growth and development, and pathogenicity [24]. For instance, Burkholderia acts as an endosymbiotic partner of Rhizopus microspores, causing rice seedling blight disease. The bacterium produces the rice-killing toxin rhizoxin and enables the fungus to produce infecting spores [25]. Additionally, fungi must compete with other organisms and among each other for resources, such as nutrients and space. Competition occurs, for instance, by secretion of secondary metabolites or by direct interaction, such as overgrowth and mycoparasitism [26]. Mycoparasitism, where one fungus attacks and invades another, significantly contributes to the suppression of pathogens. Mycoparasite Trichoderma is therefore applied in the biological control of fungal plant diseases [27]. Moreover, it was shown that fungal-bacterial interactions enable the production of specific fungal secondary metabolites [28]. It was demonstrated that exclusively close physical interaction between Aspergillus nidulans and Streptomyces rapamycinicus activates the production of specific aromatic polyketides [29]. The actinomycete thus triggers alterations in histone acetylation to affect fungal gene regulation [30]. In general, Actinomycetes are producers of many natural products with a wide range of bioactivities [31]. A study on soil-dwelling Streptomyces coelicolor interacting with other Actinobacteria showed that most of the compounds produced in each interaction were unique for the respective partnership. Many novel bioactive molecules and an extended family of acyl-desferrioxamine siderophores were identified. In total, over 200 differentially synthesized compounds were identified, including prodiginines possessing immunosuppressive and anticancer activities, actinorhodin antibiotics, and siderophores coelichelin and acyl-desferrioxamines [32]. Thus, Actinobacteria interspecies interactions seem to be very specific and complex, and harbor enormous potential to identify novel biotechnologically and medically relevant compounds [31].

Within the last decades, it became clear that fungal interactions are crucial to natural and anthropogenic ecosystems, including human health. On the one hand, fungal interactions represent a great potential to be utilized in sustainable agriculture. It is frequently suggested that arbuscular mycorrhizal may improve phosphor nutrition, enhance nitrogen uptake, or improve disease resistance in their host plants. Other microbes, e.g., nitrogen-fixing bacteria or phosphor-solubilizing bacteria, synergistically interact with those fungi and benefit plant development and growth [33]. The mycorrhizal symbiosis becomes important in sustainable agricultural systems where nutrient inputs are low and play an essential role in nutrient mobilization from crop residues [34].

On the other hand, recognizing fungal interactions with harmful properties, for instance, in human health, could lead to improved therapeutics [35]. 


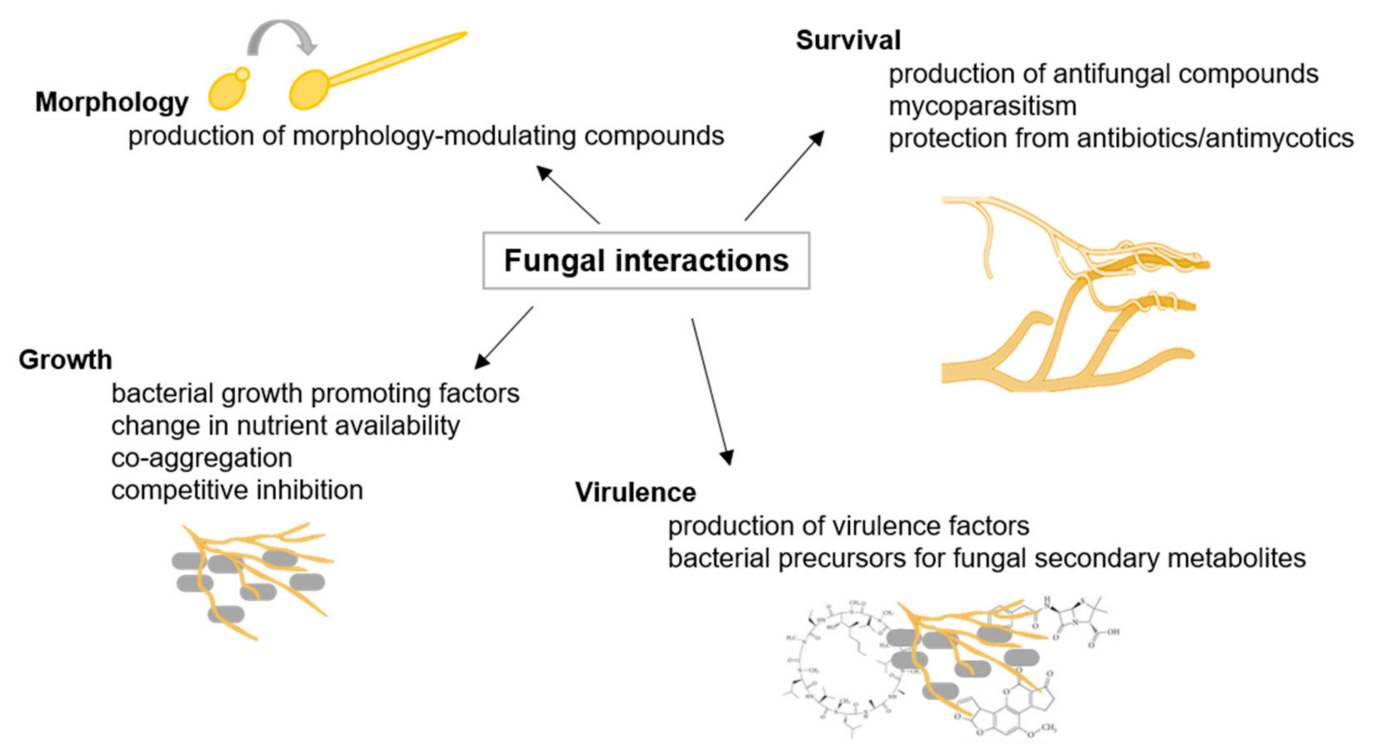

Figure 1. Fungal interactions. Examples of fungal interactions are illustrated with their respective consequences, adapted from [36].

\subsection{Archaeal Interactions}

Although archaea may be the most ancient organisms on Earth [37], only recently researchers became aware of the multiple ways in which archaea may interact with each other and with organisms of other kingdoms (as illustrated in Figure 2). In particular, methanogens take part in essential steps of the global methane cycle, which are partially conducted in a symbiotic interaction with different partners, such as herbivorous animals or sulfate-reducing bacteria [38]. No archaeal pathogen was identified until now, though some archaeal commensals may be indirectly involved in bacterial infections [39]. Mutualistic symbioses with archaeal partners were described, some of them with high relevance to global environmental cycles and others of unknown ecological significance related to highly specific mechanisms (reviewed in [38]). However, the identification and study of archaeal interactions are challenging because interactions between predominantly uncultivable or at least complicated cultivable organisms are problematic to detect [40]. Nevertheless, the archaeal symbiosis between the host Ignicoccus hospitalis and Nanoarchaeum equitans is well described even at the structural level [41]. Ignicoccus (Crenarchaeota, Desulfurococcales) is an anaerobic, hyperthermophilic obligate chemolithoautotrophic hydrogen oxidizing archaeon. The symbiont $N$. equitans directly attaches to the specialized outer membrane of Ignicoccus and obligatorily depends on the Ignicoccus host because the highly reduced genome lacks genes for essential biosynthetic pathways, such as lipid, amino acid, and nucleotide biosynthesis [42]. Consequently, biological macromolecules must be provided by Ignicoccus [43] (as illustrated in Figure 2). Another study observed stable archaeal aggregates formed by Pyrococcus furiosus and Methanopyrus kandleri, while hydrogen produced by Pyrococcus is utilized by Methanopyrus [44]. Such interspecies hydrogen transfer is also prominent for syntrophic archaea-bacteria consortia. For example, the consortium of "Methanobacillus omelianskii" comprises a methanogenic archaeon and a Gram-negative bacterium, which in syntrophy convert ethanol to acetate and methane [45,46]. A multitude of such syntrophic associations was described for hydrogenotrophic methanogens, for example, with the fermentative Acetobacterium and Syntrophobacter [47,48], Desulfovibrio under low sulfate concentrations [49], and Thermoanaerobacter, Desulfotomaculum, and Pelotomaculum under thermophilic conditions [50-52]. In addition, an essential process of methane oxidation in anoxic sediments is conducted by consortia of Euryarchaeota (ANME, anaerobic methanotroph) and sulfate-reducing bacteria (SRB), like Desulfovibrio and Desulfococcus. The partners often form small aggregates up to voluminous mats [53] (as illustrated in Figure 2). Recently, cell-cell interaction between the giant filamentous Thaumarchaeote 
candidatus, Giganthauma karukerense, and a sulfur-oxidizing Gamma-Proteobacterium was described. Here, the bacteria build a monolayer, which covers the surface of the large Thaumarchaeote filament and most likely reduces the sulfide concentration around the host cell [54].

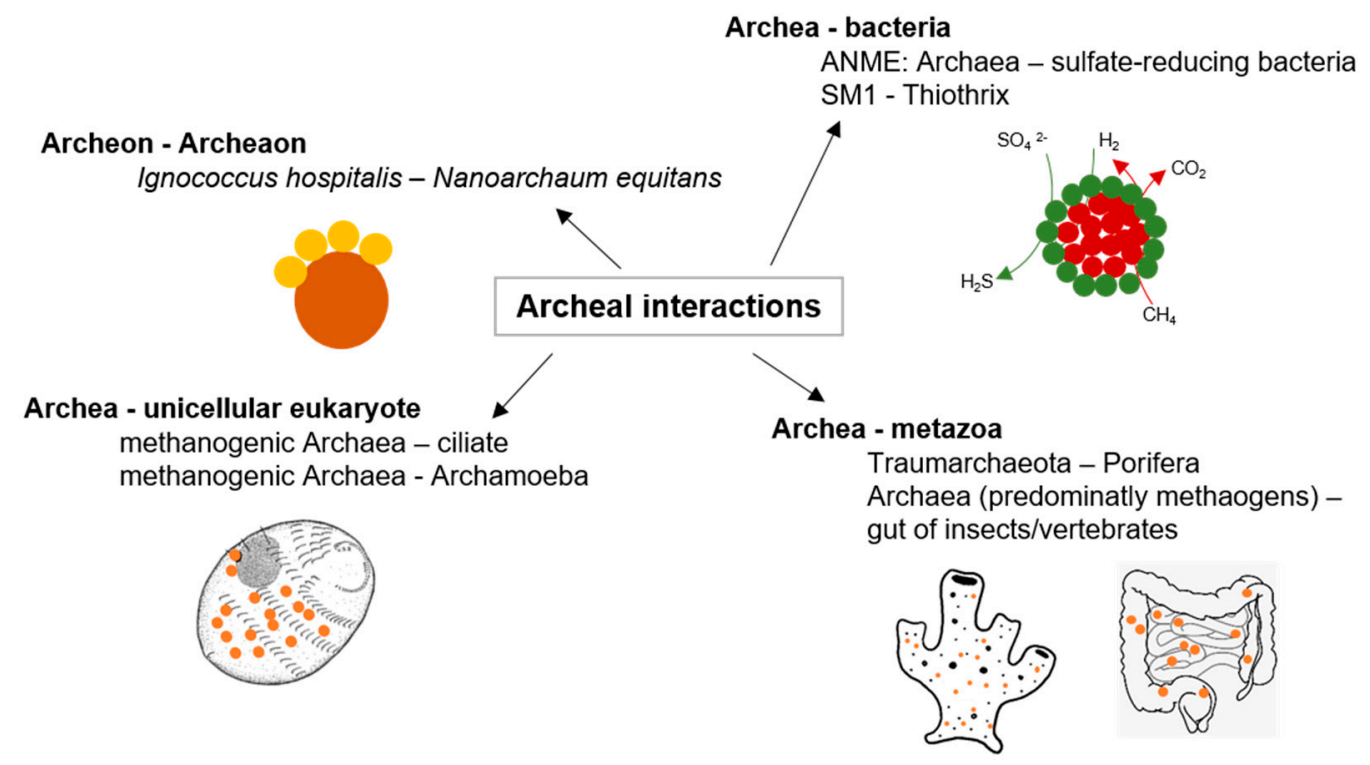

Figure 2. Archaeal interactions; examples of archaeal interactions adapted from [38].

Furthermore, methanogenic archaea are essential in the degradation of organic substrates under anaerobic conditions to methane and carbon dioxide within the guts of animals as anaerobic niches of nutrient decomposition [55] (as illustrated in Figure 2). Remarkably, a single methanogenic representative, Methanobrevibacter smithii, is the predominant archaeon in human gut microflora [56]. A syntrophic interaction between Methanobrevibacter and Bacteroides thetaiotaomicron, as studied in gnotobiotic mice, may affect the energy balance of the host. Methanobrevibacter utilizes the Bacteroides fermentation product formate. This syntrophy further determines the expression of Bacteroides enzymes [57]. Symbioses between archaea and eukaryotes, however, are not restricted to the gut anaerobic food chain. Symbioses between methanogens and protists are also well known (as illustrated in Figure 2). Here, the archaea are directly attached to the hydrogenosomes of anaerobic protozoa and ciliates [58]. Archaea are also ubiquitous in marine sponges, sometimes even dominant [59], though their ecological role is almost unknown, but were recently correlated to sponge nitrogen metabolism [60-62] (as illustrated in Figure 2). Interactions between archaea and other organisms are definitely as specific and widespread as bacterial interactions, but so far, the underlying mechanisms are still poorly understood. The findings mentioned above give just an impression on the abundance and diversity of archaeal interactions. Future studies with archaeal model organisms might lead to insights comparable with that of those achieved with bacterial models like E. coli and Pseudomonas aeruginosa [38].

\subsection{Virus-Bacteria Interactions}

Viral interactions are ecologically fundamental since viruses are responsible for many diseases in various eu- and prokaryotic hosts [63]. The present review focuses on the viruses infecting bacteria and the modulation of bacterial communities through those (bacterio) phages. Phages are the most abundant microorganisms in the biosphere, with an estimated $4.8 \times 10^{31}$ particles [64]. Phages are present in all areas, coexisting parallel to their bacterial hosts in the majority of ecosystems [65]. Phages are well known as drivers of microbial diversity, vectors of horizontal gene transfer, sources of diagnostic and genetic tools, and therapeutics [65]. Bacteriophages are natural killers of bacteria and can be 
classified according to their genome, morphology, biological cycle, or provenance [66]. A prominent distinguishing feature of phages is their biological cycle [67]. There are two main types, the lytic and lysogenic cycle (as illustrated in Figure 3). During the lytic cycle, phages attach to the host cell's surface to inject their nucleic acids into the cell. Subsequently, the host cell DNA is degraded, and the host metabolism is directed to initiate phage biosynthesis. The phage nucleic acids replicate inside the bacterium. Accordingly, entire viral phage particles are assembled, which are released from the infected cell through lysis of the bacterial cell. In contrast, the lysogenic cycle is based on the integration of the genetic material of the phage into the genome of the host cell to produce a prophage (or temperate phage). When the bacterium reproduces, the prophage is also copied and passed to each daughter cell. The daughter cells can continue to replicate with the prophage, or the prophage can exit the bacterial chromosome to initiate the lytic cycle [68]. The initiation of phage infection is triggered by the specific recognition between the phage-binding protein located at the tip of the tail or the capsid envelope and a receptor located on the host cell's surface [69]. Cell surface receptors recognized by the phage may include protein receptors (OmpA and OmpC), lipopolysaccharide (LPS) receptors, receptors located in capsular polysaccharides (Vi-antigen), and pili and flagella [70].

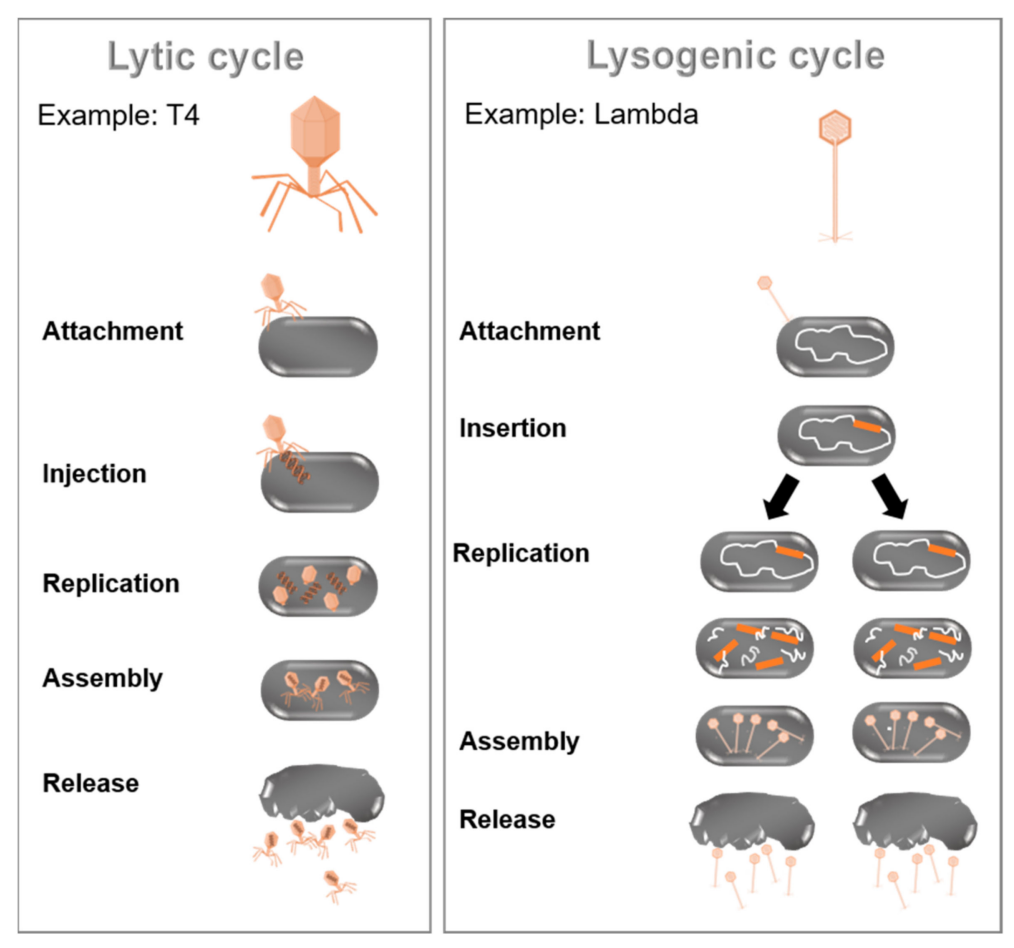

Figure 3. Phage proliferation. (Left) Infection by lytic phages like E. coli phage T4 leads to the multiplication of virus and subsequent lysis of bacterial host cell. (Right) In lysogenic cycle, phage genome (e.g., of E. coli phage Lambda) is integrated into bacterial chromosome, and an inactive prophage is replicated as part of host chromosome. Environmental triggers cause excision of phage genome and entry into lytic cycle.

Interactions with phages can cause benefit or harm to individual cells or entire communities because interactions range from mutualistic to commensal up to parasitic, including the transmission of novel bacterial phenotypes, modulation of bacterial gene expression and evolution, and killing of bacteria [71]. Some temperate phages can modulate bacterial physiology, such as E. coli phage $\mathrm{Mu}$, which integrates randomly within the bacterial genome, mutagenizing an infected population and eliminating those cells with insertions in essential genes [72]. Lytic phages modulate microbial communities by simply lysing infected cells. There is increasing evidence from aquatic habitats that phages massively affect bacterial diversity, bacterial virulence, bacterial evolvability, and even shape the stability of 
ecosystems [73]. Phages also alter the structure and function of microbial communities via horizontal gene transfer mediated by generalized transduction and transformation [74]. Prophages enhance bacterial defenses against invading phages by blocking almost every step of viral infection and replication, including adsorption, DNA injection, transcription, or even induction of altruistic suicide of the hosts. Moreover, phages modulate eukaryotic physiology [71]. Phage-conditioned changes in microbial community compositions were associated with various diseases, including Crohn's disease and ulcerative colitis (expansion in phage richness) and type I diabetes (diminished phage richness and diversity) [75]. Bacteriophage research nowadays increasingly focuses on the potential of phages to treat bacterial infections and contaminations [76,77]. The worldwide increase of pathogenic bacteria resistant to antibiotics requires alternative strategies to combat this threat [78]. Phage therapy has a tradition dating back almost a century, but further development slowed down in Western countries when antibiotics were discovered [77]. The therapeutic use of bacteriophages is one promising strategy in the medical field, food industry, and agri- and aquaculture. Many attributes of phages suggest a positive outcome in therapy, both by preventing contaminations and treating ongoing infections, particularly biofilm infections [79]. As demonstrated, phage-bacteria interactions are manifold, but their study, particularly for interactions with archaea and fungi, lags. Similarly, less knowledge is available about phage-phage interactions, which can affect the course of bacteria-phage interactions, with implications for the microbial community and associated multicellular organisms. Novel technologies, such as sequencing viromes from nature, imaging of viruses, and genetic engineering for a molecular understanding of the underlying interactions, direct future research and ultimately enable gaining insights into those fundamental relationships [65].

\subsection{Bacteria-Bacteria Interactions}

Interactions between bacteria, either between cells of the same species or between different bacterial species, are manifold and ubiquitous in nature [23] (as illustrated in Figure 4). Bacterial interactions got into focus by case studies on communication and cooperative behavior among myxobacteria, Quorum Sensing (QS), and biofilm formation of Pseudomonas [80]. Recently, cooperative behaviors among bacteria were increasingly considered in evolutionary biology [4]. Extracellular signal molecules produced by bacterial cells can be detected by other cells and regulate the expression of genes. In some bacteria, siderophores are synthesized for microbial community interactions [23,81]. In Pseudomonas spp., pyoverdine siderophores are essential for infection and biofilm formation, and may potentially help to regulate bacterial growth [82]. In the marine environment, exogenous siderophores act as signaling compounds that influence the growth of marine bacteria under iron-limited conditions. Many marine bacteria were reported to produce ironregulated outer membrane proteins exclusively in the presence of exogenous siderophores produced by other species, such as $N, N^{\prime}$-bis (2,3-dihydroxy benzoyl)-O-serylserine from Vibrio sp. [83]. Various cooperative and competitive bacterial interactions rely on synthesizing and detecting small chemical signaling molecules in a communication process called QS (QS). Several social behaviors of bacteria are triggered or affected by QS, such as virulence, pathogenicity, and biofilm formation [84]. Although the molecular structures of the signaling molecules, the organization of the sensing machinery, and the functional consequences of the signaling process show significant diversity among different bacteria, the biological similarity of these processes is undeniable [85]. In the following, biofilms are examined in more detail as the most common form of syntrophic microbial consortium in nature. Moreover, QS as a fundamental and universal communication strategy of bacteria within the domain of bacteria and among different domains is considered and QS-regulated behaviors are highlighted. Finally, interference with bacterial cell-cell communication (Quorum Quenching, QQ) is discussed as a natural mechanism for recycling own QS signals and in the context of a competitive relationship. Further, QQ is considered a natural occurring strategy to prevent and inhibit colonization of (antibiotic-resistant) bacteria, particularly those embedded in a biofilm, with promising potential for future applications. 
Syntrophy - bacterial relationship, in which one or both benefit nutritionally from the presence of the other

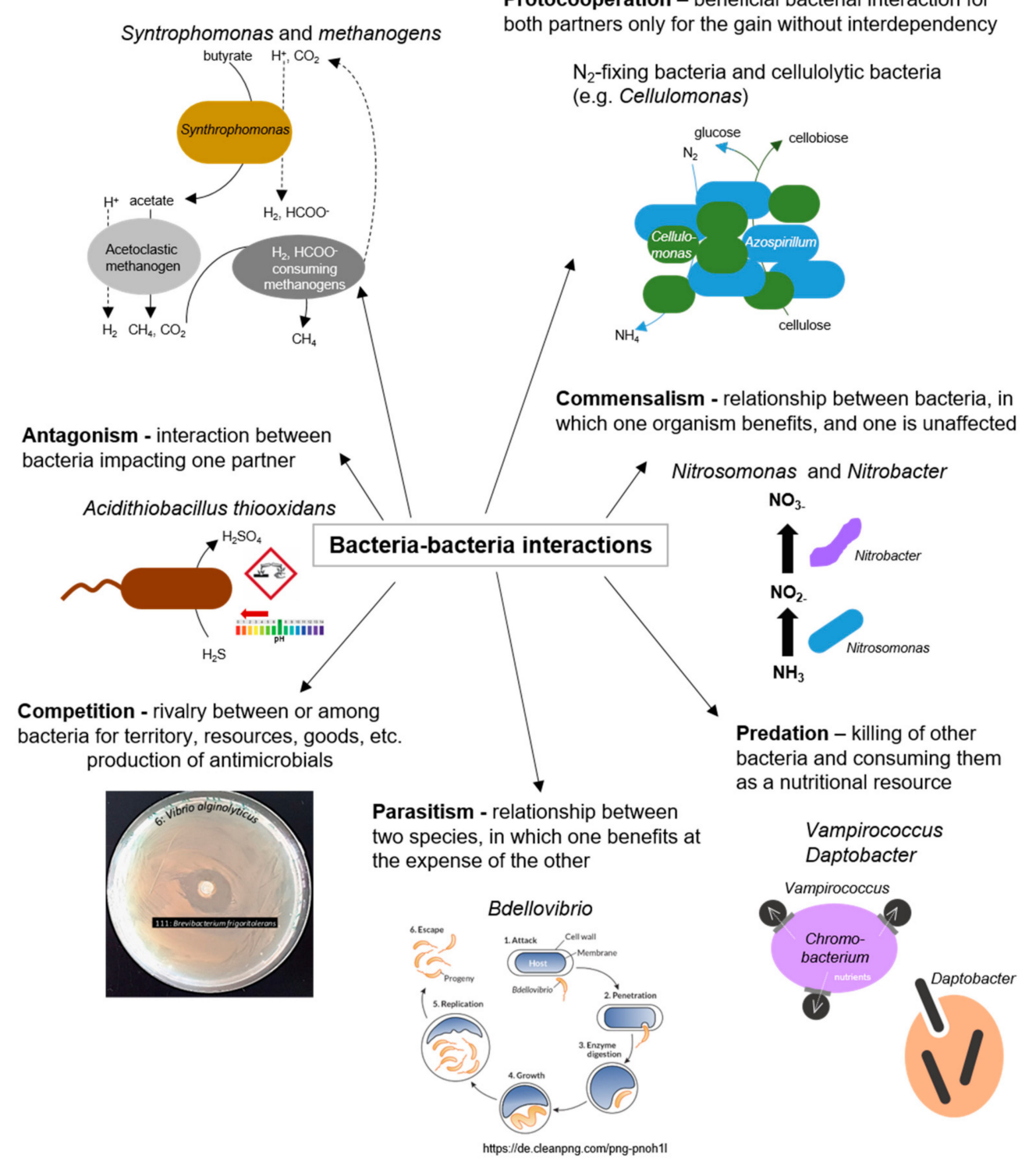

Figure 4. Bacteria-bacteria interactions; examples of positive and negative interactions among bacterial species.

\subsubsection{Biofilms}

Biofilms are one of the most widely distributed and successful modes of microbial life [86]. A biofilm is defined as an aggregate of microorganisms in which cells are embedded in a self-produced matrix of extracellular polymeric substances (EPS) [87]. The interaction of cells initiates biofilm formation with a surface or with each other. It is supposed that the planktonic bacteria adhere to the surface initially through reversible adhesion via van der Waals forces. Attached cells proliferate and produce an extracellular matrix to form microcolonies, in which communication among the cells through biochemical signals and a genetic exchange is facilitated. The matrix contains exopolysaccharides, extracellular DNA, RNA, and proteins. Cells further proliferate, and spatial structuring occurs in all dimensions, resulting in a mature three-dimensional biofilm. Over time, microcolonies undergo cell death and lysis along with active dispersal of motile bacteria [88] (as illustrated in Figure 5). A biofilm is assumed to maintain an equilibrium through growth and dispersal [89]. Biofilms are complex systems typically comprising many species of high cell densities, ranging from $10^{8}$ to $10^{11}$ cells/g wet weight [90]. Biofilms drive bio- 
geochemical cycling processes of most elements in water, soil, sediment, and subsurface environments. All higher organisms are colonized by biofilms, which can be correlated with persistent infections in plants and animals, including humans [1]. Furthermore, biofilms cause contamination of medical devices and implants, biofouling, contamination of process water or even drinking water, and corrosion [91]. In contrast, biofilms are used in biotechnological applications, including filtration of drinking water, degradation of waste (water), and biocatalysis of biotechnological processes, such as producing bulk and fine chemicals as well as biofuels [92].

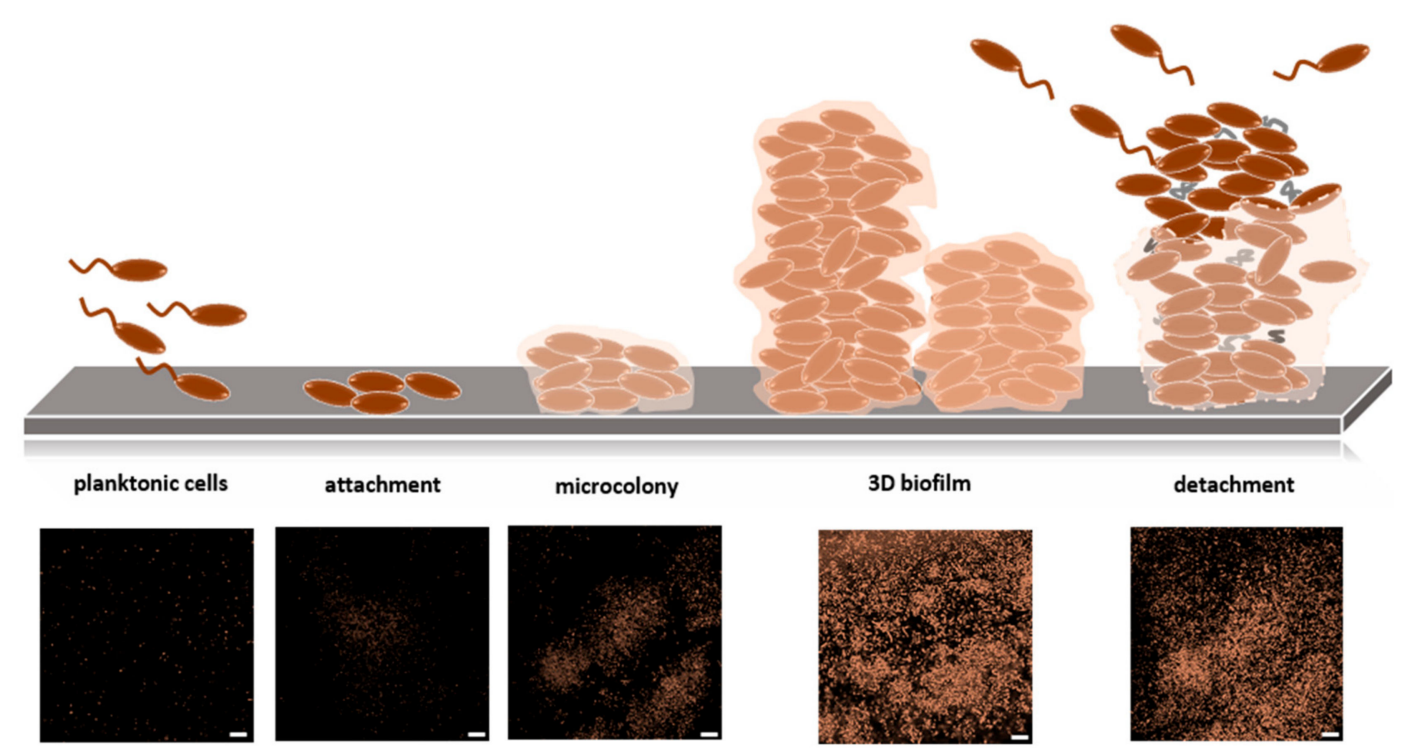

Figure 5. Biofilm development. (Upper panel) Free-swimming bacteria initially attach to a solid surface, and colonizing bacteria further form structured aggregates called microcolonies. Biofilms are composed of numerous microcolonies, which are encased in an extracellular polymeric matrix. Biofilms permanently undergo composition/decomposition. (Lower panel) Confocal Laser Scanning Micrographs of Klebsiella oxytoca M5aI biofilm formation.

The biofilm lifestyle is distinct from that of free-living bacterial cells. Biofilm communities have emergent properties, like physical, metabolic, and social interactions, including enhanced gene exchange and increased tolerance to antimicrobials [93]. Tolerance in biofilms can result from both the biofilm matrix acting as diffusion barrier and inactivation zone of antimicrobials and slowed growth of biofilm cells, even leading to the dormancy of cells. Further, a high proportion of stationary cells (persisters) with changed metabolic performance were detected in biofilms [93]. Resistance of cells in the biofilm to antimicrobials can also occur by the uptake of resistance genes through horizontal gene transfer, since genetic competence and accumulation of mobile genetic elements is increased in biofilms [94]. The organization in biofilms allows and promotes interactions for a myriad of organisms due to the created proximity. Proximity enables the exchange of metabolites, signaling molecules, and genetic material between organisms [86] (as illustrated in Figure 4). Furthermore, heterogeneity, such as cells with different metabolic capacities or physiological gradients, provides opportunities for cooperation [95]. The heterogeneous physiological activity in biofilms produces vertical gradients of electron acceptors and donors, $\mathrm{pH}$ value, and redox conditions [96]. One of the most important external triggers of the establishment of gradients is the availability of electron acceptors such as oxygen, resulting in aerobic microcolonies in the upper layer of the biofilm and the formation of anaerobic zones in deep layers [97]. Heterogeneity in biofilms also enables spatial organization of mixed species such as in microbial mats. Here, phototrophic microorganisms, e.g., algae, cyanobacteria, and anoxygenic phototrophic bacteria generate and release organic substrates as exudates, which are used from neighboring heterotrophic species in close proximity, thus enhancing their metabolic activity [98] (as illustrated in Figure 4). 
Metabolic interactions between different species in biofilms can also be observed in the process of nitrification, in which ammonia-oxidizing bacteria convert ammonium into nitrite, which is subsequently oxidized by nitrite-oxidizing bacteria [18] (as illustrated in Figure 4). Examples of cometabolism or metabolic sharing lead to more efficient resource partition between community members, further supporting the concept of coevolution of biofilm members [86]. Cooperation does not necessarily occur in all biofilms, and it was even suggested that most species-species interactions in biofilms are negative, since cells are competing with each other [23]. Competition mechanisms in biofilms include antibiotics, bacteriocins, extracellular membrane vesicles, and type VI secretion systems. This ultimately causes inhibition of initial adhesion of the biofilm, surface colonization (e.g., swimming and swarming of P. aeruginosa cells on the surface, thereby preventing the adhesion of competing Agrobacterium tumefaciens cells [99]), or the production of biosurfactants with antimicrobial properties [100] (as illustrated in Figure 4). Furthermore, invaders can inhibit the maturation of a biofilm and promote its dispersal through downregulation of adhesin synthesis, inhibition of cell-cell communication, or degradation of matrix polysaccharides, nucleic acids, and proteins [101].

In conclusion, numerous biofilm studies identified fundamental principles that underlie many of the key properties and phenotypes of biofilms, e.g., cell-cell interactions, spatial structuring, and heterogeneity. Although studies of microbial consortia in natural settings were revolutionized by metagenomics, most insights were gained with less complex biofilm communities in the laboratory, often neglecting spatial and temporal scales of microbial interactions in the assemblages [3]. Understanding how to disrupt or promote the function of biofilm communities, which are recognized as the primary form of bacterial life in nature, is a priority for modern microbiology [95]. Consequently, extensive knowledge gain on QS, which plays a crucial role in biofilm formation for various bacterial species, is essential and would have immense implications for an improved understanding of microbial ecology and the treatment of microbial infections.

\subsubsection{Bacterial Communication-Quorum Sensing}

Many bacteria use a cell-cell communication system called Quorum Sensing to coordinate population density-dependent behaviors [80]. QS is based on the synthesis and perception of low molecular weight molecules, so-called autoinducers (AI), which either diffuse over the cytoplasmic membrane or are actively transported and detected explicitly by a specific receptor (as illustrated in Figure 6). When the AI binds its corresponding receptor, the subsequent signal transduction is activating the transcription of target genes, often including those encoding the respective AI synthase (autoregulation) [102]. When the population density increases, the concentration of the signaling molecule is passing a threshold ("quorum"), thus causing more autoinducers to be synthesized through the induction of AI synthase. This forms a positive feedback loop, and the receptor becomes fully activated. Activation of the receptor changes the regulation of target genes, leading to synchronized transcription in the population [103]. Thus, cell density-dependent behaviors are coordinated (for review, see [104]), e.g., colonization, virulence, pathogenicity, and biofilm formation as mentioned above $[105,106]$.

QS systems were found in both Gram-negative and Gram-positive bacteria [107]. Gram-negative bacteria communicate via acylated homoserine lactones (AHLs) (as illustrated in Figure 6A) [104]. The first description of QS was on the bioluminescent marine bacterium Vibrio fischeri. At high cell densities, in symbiotic association with the Hawaiian bobtail squid Euprymna scolopes, $V$. fischeri activates bioluminescence through QS and supports the squid in masking its shadow during predator avoidance. Two components, LuxI and LuxR, impact the expression of target genes, e.g., the lux operon (luxICDABE) responsible for bioluminescence in $V$. fischeri [108]. Similar AHL QS systems were since shown to be widely distributed in Gram-negative bacteria controlling diverse behaviors, such as the production of secreted toxins and virulence factors, biofilm formation, and conjugation. Many bacteria harbor more than one signal-receptor combination [109]. For 
example, P. aeruginosa has two complete LuxRI-type homologs, LasRI and RhlRI, which operate in a hierarchy [110]; and B. thailandensis has even three LuxRI homologs [111]. It was proposed that energy-costly resourcing of different AHL communication systems might provide specific benefits in different environments [112]. Gram-positive bacteria communicate using modified oligopeptides and two-component regulatory systems (as illustrated in Figure 6B). Briefly, the signaling molecules are either unmodified or posttranslationally modified small peptides secreted via ABC exporter proteins. Phosphorylation of the receptor kinase due to peptide binding activates the regulatory protein, which acts as a QS target gene transcription factor [113]. Virulence factor production in Bacillus cereus and Staphylococcus aureus, the competence of B. subtilis, and the biofilm formation of Streptococcus pneumonia are only a few examples of QS-dependent gene regulation in Gram-positive bacteria $[114,115]$. QS allows bacteria not only to communicate within their own, but also between different bacterial species. Therefore, autoinducer-2 (AI-2) is synthesized and recognized by many different bacterial species. Thus AI-2 appears to be an almost universal signal (as illustrated in Figure 6C) [116]. The AI-2 system was first described in V.harveyi [117]. The AI-2 synthase, called LuxS, produces the AI-2 precursor, 4,5-dihydroxy2,3-pentadione (DPD) [117]. DPD can spontaneously cyclize to generate some isoforms, collectively referred to as AI-2 [118-120]. Different isoforms bind different signal receptors; for instance, the S-form binds to the signal receptor LuxP in V. harveyi, whereas the R-form binds to the LsrB receptor protein in Salmonella enterica serovar Typhimurium or E. coli [121]. For instance, it was reported that AI-2 is involved in the regulation of bacteriocin production and biofilm formation in S. mutans, biofilm formation of S. anginosus and Listeria monocytogenes, virulence regulation of S. pneumonia and S. pyogenes, and toxin production in Clostridium (reviewed in [122]). In general, the bacterial response to certain autoinducers is manifold and adaptable. Vastly different bacterial genera can detect the same compound as in the case of AI-2. Slightly modified molecules of the same chemical class even activate different responses among different species of the same genus [123]. Correspondingly, a number of chemically different QS molecules act jointly in a particular organism [124].

Recent studies further focused on the role of QS in cooperative and competitive microbial interactions, thus concentrating on QS as a social behavior [80]. Many QSregulated products are secreted or excreted products, such as secreted proteases, and can thus be used by any community member, although its synthesis implies a metabolic cost for only one individual cell [125]. QS-dependent cooperation was for instance demonstrated for regulated production of elastase in P. aeruginosa, a protease required for growth when populations are cultivated on casein as the sole source of carbon and energy [126,127]. In addition, bacterial swarming is a social trait due to the joint production of secreted surfactants in several bacterial species, including P. aeruginosa and B. subtilis [128-130]. In contrast, various bacterial species use QS to control the production of secreted or cell-targeted toxins, for example, bacteriocins in Streptococcus species [131,132] and type VI secretion effectors in $B$. thailandensis [133]. In soil communities, P. fluorescens and $P$. aureofaciens use QS-regulated phenazines to fight the fungus Gaeumannomyces graminis and colonize the plant [134]. AHL-dependent competition was likewise observed for $P$. aeruginosa and $S$. aureus mixed communities, which commonly coculture in chronic wound infections. P. aeruginosa usually surpasses or decreases the S. aureus population by QSregulated synthesis of compounds, which block $S$. aureus oxidative respiration, such as 4-hydroxy-2-heptylquinoline $N$-oxide or pyocyanin. Subsequently, P. aeruginosa induces $S$. aureus cell lysis by the QS-regulated protease LasA [135]. 
$A$

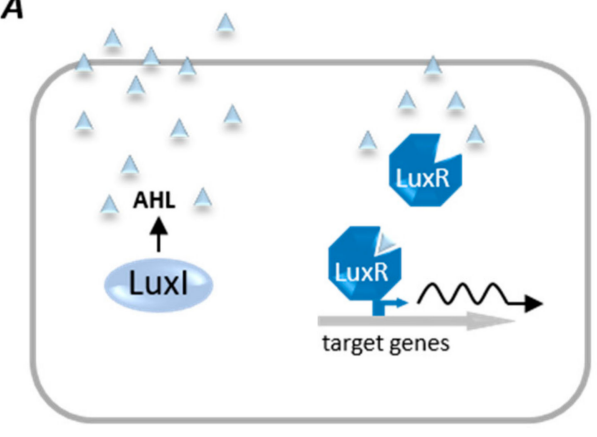

C

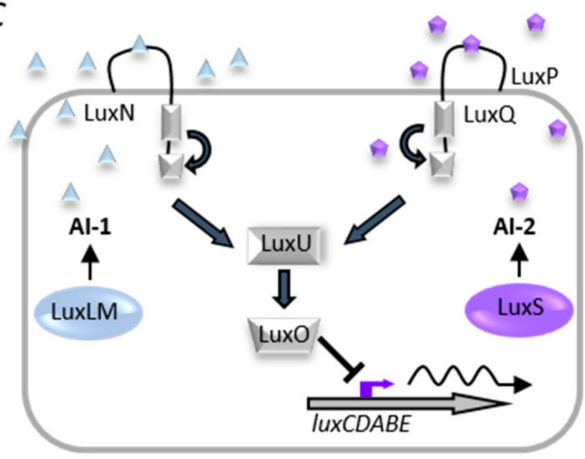

B

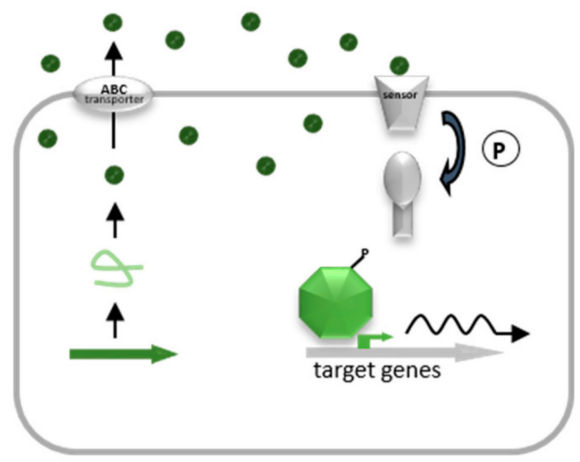

$D$

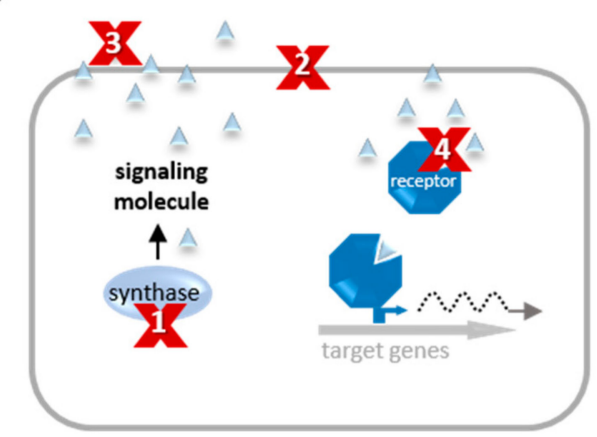

Figure 6. Quorum sensing (QS) systems and Quorum quenching (QQ) strategies. (A) Gram-negative bacteria produce diffusible autoinducers (AI, triangles) by a LuxI homologous synthase. AIs diffuse into the cell and bind to cognate receptor (LuxR homolog). This complex binds at target gene promoters and activates their transcription. (B) A precursor peptide (loop) is produced and modified (circles) by Gram-positive bacteria and then secreted via an ATP-binding cassette (ABC). A two-component system detects signaling molecules, and phosphorylated response protein binds to specific promoter genes to modulate their expression. (C) The QS system of $V$. harveyi combines Gram-negative and Gram-positive QS elements, in which acyl-homoserine lactones (AI-1, triangles) are synthesized by LuxLM, and a second universal AI (AI-2, pentagons) is synthesized by the enzyme LuxS. AIs are detected by two-component systems whose signals are transduced by phosphorelay and end in the expression of the luciferase structural operon (luxCDABE). (D) Examples of QQ strategies. (1) inhibition of AI biosynthesis; (2) inhibition of signal transport; (3) degradation, modification, or antagonism of AIs, and (4) inhibition of signal recognition.

Moreover, recent evidence shows that QS is not restricted to the domain of bacteria, but also shows that QS is not restricted to bacteria and allows communication between bacteria and their hosts. In the meantime, scientists comprehended that these bacterial signals modulate mammalian cell signal transduction [136], and that host hormones can crosstalk with QS signals to modulate bacterial gene expression [137]. These observations are not surprising since prokaryotes and eukaryotes coexisted for millions of years, and the development of eukaryotes depended on bacterial communities [138]. The research field of "interkingdom signaling" is still in its infancy, but the increasing number of publications in this area demonstrates that microbial-host communication is in the spotlight. Prominent examples of microbial-host communication are presented in the following, which disclose their importance for bacteria-host interactions. The first example of QS between bacteria and plants was found in the relationship between the marine bacterium V. anguillarum and the green seaweed Enteromorpha [139]. Biofilm-forming Vibrio cells release AHLs and attract zoospores, the motile reproductive stage of the seaweed, which subsequently settle to establish and develop in a certain habitat. In the meantime, several QS-dependent seaweed-microbe interactions are known (for review, see [140]). The first demonstration of a specific response of a plant to bacterial AHLs was shown for the legumes Phaseolus vulgaris [141] and Medicago truncatula [142]. Here, AHLs from both symbiotic (Sinorhizobium meliloti) and pathogenic (P. aeruginosa) bacteria caused significant changes in the plants' 
gene expression. In addition, Gao et al. have shown that $M$. truncatula responds to bacterial communication by producing its small molecule AHL-mimics [143]. The most studied plant-bacteria interaction in the marine environment is the red alga Delisea pulchra, which secretes brominated furanones to protect from fouling microorganisms. The algae release those brominated furanones, which inhibit multiple AHL-dependent processes, including swarming motility in Serratia liquefaciens and bioluminescence in Vibrio spp. as well as AI-2-based QS in Vibrio spp. [144,145]. Due to their QS inhibitory effects, halogenated furanones showed practical potential for treating disease in shrimp aquaculture and reduced the virulence of P. aeruginosa in mouse models [146]. Moreover, one of the best-studied interkingdom signaling mechanisms with plant hosts is the relationship between Rhizobium spp. and their symbiotic legume host. In this symbiosis, complex exchange of signals between bacteria and the plant leads to the successful formation of root nodules, in which bacteria reside and fix atmospheric nitrogen [147]. Plants evolved multiple mechanisms to interpret bacterial QS signals and initiate attraction/defense responses in a tissue-specific manner, which are even signal-specific [142,148]. Fungi also communicate by small signaling molecules and even talk to bacteria in their vicinity [149]. However, fungi were not shown to produce bacterial autoinducer analogs [150]. The most prominent example is the yeast Candida albicans, whose QS molecule farnesol acts in a cell density-dependent manner and causes a morphological switch between yeast and hyphae [151]. Since the discovery of farnesol, QS was described in several other fungal species and was shown to be involved in regulating growth, stress resistance, morphogenesis, and biofilm formation [149,152]. So far, identified fungal QS molecules include peptides, e.g., of Cryptococcus neoformans [153], oxylipins in A. nidulans [154], and alcohols and their derivatives such as tyrosol in C. albicans [155]. Furthermore, there is increasing experimental evidence that bacteria can recognize mammalian hormones. Here, research mostly focuses on pathogens, which turn on their production of virulence factors to respond to mammalian hormones. The AI-3/epinephrine/norepinephrine signaling system is a prime example. The enteric pathogen E. coli senses AI-3 produced by the microbial gastrointestinal (GI) community to activate virulence genes resulting in colon lesions. Eukaryotic hormones epinephrine and norepinephrine present in the GI tract activate the expression of the virulence genes in enterohemorrhagic E. coli (EHEC) [137]. Thus, EHEC captures the eukaryotic hormones, subsequently promoting colonization of the human colon mucosa that causes colon lesions. Such an adrenergic regulation of virulence seems not to be restricted to EHEC. In silico analyses observed this form of interaction in other bacterial species such as Salmonella spec., Shigella flexneri, Francisella tularensis, H. influenzae, Erwinia carotovoa, Pasteurella multocida, Ralstonia eutropha, Chromobacterium violaceum, and V. parahaemolyticus [156,157]. In addition, opioids such as endorphin and dynorphin are known as novel hormones hijacked by pathogenic bacteria like $P$. aeruginosa. The bacteria recognize those opioids to enhance their virulence by increasing the production of their QS systems leading to persistent $P$. aeruginosa colonization in the lungs of cystic fibrosis patients [158]. Besides the mentioned involvement of AIs in bacterial pathogenesis, likewise the effects of AIs on eukaryotic cells should not be dismissed. There is increasing evidence that AIs, i.e., 3-oxo-C12 homoserine lactone (HSL), are able to modulate signal transduction and immune responses of the eukaryotic host [159]. In addition, high concentrations of 3-oxo-C12-HSL induced apoptosis due to calcium mobilization from the endoplasmic reticulum [160]. In contrast to the detrimental effects caused by the QS signals of P. aeruginosa, a study by Fujiya et al. suggests a cooperative bacteria-host relationship mediated by bacterial QS [161]. Gram-positive B. subtilis synthesize a pentapeptide (competence and sporulation factor, CSF) to regulate expression of competence and sporulation. Nevertheless, CSF also activates two crucial kinase-dependent survival pathways in intestinal epithelial cells by preventing cell injury and loss of barrier function [161].

The numerous examples of QS involvement within the bacterial domain and among domains leading to cooperative and competitive interactions point to the importance of this fundamental communication system. Since many bacteria use QS to control the expression 
of virulence factors, regulate pathogenicity and biofilm formation, the interference with this cell-cell communication mechanism further constitutes a novel and promising strategy to control bacterial infectious diseases [162-165].

\subsubsection{Interference with Bacterial Communication-Quorum Quenching}

The term "Quorum Quenching" (QQ) describes all processes that interfere with bacterial cell-cell communication [166]. In a polymicrobial community, some bacteria are communicating with neighboring cells by QS, while others are interrupting the communication due to QQ mechanisms; thus, long time thought of as primarily operating as a defense mechanism against competitors $[84,90,167]$. The different $Q Q$ mechanisms operate by blocking different steps involved in QS, comprising (i) blocking signal generation and accumulation, (ii) preventing signal reception, and (iii) inhibiting autoinduction and activation [109] (as illustrated in Figure 6D). (i) Firstly, inhibition of signal molecule biosynthesis can be achieved by inhibiting involved enzymes as the acyl chain (acyl-acyl carrier protein) (ACP) and S-adenosylmethionine synthase, or interfering with the synthases themselves as LuxI homologs and LuxS [165]. (ii) Secondly, several small molecules that mimic or deactivate the complex interactions between the signaling molecule and their protein receptors were identified [168]. A distinction is made between an agonist, implying a function like the native AHL based on the mimic structure and an antagonist blocking the receptor binding site prevents binding of the signaling molecule [169]. For instance, an AHL agonist for $P$. aeruginosa was identified, which shows no obvious structural connection to the AHL (3-oxo-C12-HSL) but was predicted to bind in the same protein pocket of the receptor protein as the AHL [170]. In addition, a series of naturally occurring bromo-furanones exhibit potent antagonistic QS inhibition and appear to function by disturbing the dimerization of the receptor protein and not by competitive binding at the ligand site [171]. Further, diketopiperazines (DKP) are cyclic dipeptides, which share structural similarities to signaling peptides in mammalian tissues. They are produced by various bacteria such as P. aeruginosa, Proteus mirabilis, Citrobacter freundii, and Enterobacter agglomerans [172], and yeast, fungi, and lichens [173]. DKP act as AHL antagonists in LuxR-based QS and as agonists in others [172]. Also, cross-inhibition by autoinducing peptides (AIPs) of Gram-positive bacteria in S. aureus represents an example of QQ mechanism by inhibitors because each of the four AIPs present in S. aureus specifically inhibits QS in competitive S. aureus groups [174]. Each AIP specifically activates its cognate receptor but inhibits activation of all others by competitive binding to the noncognate receptors. Thus, each AIP inhibits activation of the virulence cascade in the other three groups of $S$. aureus. Coinfection with two different $S$. aureus groups results in intraspecies competition; the $S$. aureus group that first establishes its QS cascade suppresses the other group [175]. Based on the importance of S-ribosylhomocysteine (SRH) in synthesizing the precursor DPD for the generation of universal signaling molecule AI-2, several research groups found substrate analogs of SRH potential inhibitors that target AI-2 synthesis. SRH analogs, S-anhydroribosyl-L-homocysteine and S-homoribosyl-L-cysteine, exhibited inhibitory activities against LuxS [176]. Several SRH analogs were further reported as potential LuxS inhibitors. Kinetic studies indicate that these compounds act as reversible, competitive inhibitors against LuxS [177]. As SRH is the most important intermediate for the synthesis of DPD, 5-methylthioadenosine nucleosidase (MTAN) is also important as an enzyme during the synthesis process. MTAN is encoded by the pfs gene in bacteria and catalyzes the hydrolytic deadenylation of its substrates to form adenine and S-ribosylhomocysteine. According to the mechanism of the reaction catalyzed by MTAN, several transition state analogs, e.g., But-DADMe-ImmA, were designed and synthesized, inhibiting AI-2 synthesis [178]. Moreover, several agonist ligands were reported for $V$. harveyi receptor protein LuxP, most of which are DPD or AI-2 (S-THMF-borate) analogs competing for binding to LuxP with natural AI-2 [179,180]. Ren et al. found that the natural furanone compound (5Z)-4-bromo-5-(bromomethylene)-3butyl-2(5H)-furanone could inhibit the AI-2-mediated QS in V. harveyi and E. coli [181]. A screening of many samples from plants, ursolic acid, and 7-hydroxy indole was found as 
inhibitors for enterohemorrhagic E. coli biofilms by blocking the AI-2 pathway [182,183]. Previous research showed that certain food components inhibit AI-2 signaling using reporter strain $V$. harveyi BB170 [184]. AI-2 QS inhibitors in poultry meat wash samples were characterized by identifying several quenching fatty acids. Linoleic acid, oleic acid, palmitic acid, and stearic acid expressed AI-2 inhibition ranging from approximately 25-99\% [185]. (iii) Thirdly, modification or degradation of the QS signaling molecules prevent them from accumulating. QS signal degradation can be mediated by chemical, metabolic, and enzymatic mechanisms [186]. The chemical degradation was reported primarily at alkaline $\mathrm{pH}$, leading to the opening of the lactone ring of AHLs [187]. However, at acidic $\mathrm{pH}$, the ring recyclizes, and the activity is restored. A few organisms such as Variovorax paradoxus and $P$. aeruginosa can metabolize AHLs as the sole carbon source, thus suppressing competitive QS bacteria parallel to energy generation [188,189]. Enzymatic degradation of QS signaling molecules was observed in a wide range of prokaryotes and eukaryotes. AHL-lactonases hydrolyze the ester bond of the homoserine lactone ring of AHL molecules [190]. The first reported AHL-lactonase encoded by the aiiA gene was characterized from Bacillus isolate 240B1 [191]. Homologs were identified in a range of bacteria, including Gram-positive and Gram-negative species. AHL-lactonases can be grouped into two clusters based on their sequence homologies. The first one is the AiiA cluster with representatives from Bacillus [192]. The second one is the AttM cluster with Gram-negative members, e.g., A. tumefaciens and Klebsiella pneumoniae $[193,194]$. AHL-lactonases are by far the most specific AHL-degrading enzymes among known QQ enzymes. They hydrolyze both short- and long-chain AHLs but show no residue activity to other small molecules [195]. Paraoxonases (PON) were identified in mammals, other vertebrates, and invertebrates $[196,197]$ and are also capable of hydrolyzing the homoserine lactone ring of AHLs [173]. PON enzymes seem to be most active with long-chain AHL molecules, often used by eukaryotic pathogens, e.g., $P$. aeruginosa [198]. PONs are well known for their broad-spectrum enzyme activities, unlike lactonases [199]. AHL-acylases inactivate AHL signals by cleaving the amide bond of AHL, thus producing the corresponding fatty acids and homoserine lactone [188]. These enzymes are widely conserved in several bacteria, including Variovorax, Ralstonia, and $P$. aeruginosa [200,201]. There are notable differences in the substrate specificities among AHLacylases, which are demonstrated in the effectiveness of degrading long-chain AHLs [202]. AHL-oxidoreductases do not degrade AHLs but modify the 3-oxo group of the molecule to generate corresponding 3-hydroxy derivates [203]. Depending on the specificity of the AHL receptor, the modification may or may not affect the signaling activity of the respective AHL [204]. Quenching of Gram-positive signaling is, for instance, enabled by NADPH oxidases located in the membranes of phagocytes, which are responsible for the generation of bactericidal reactive oxygen species during host defense and essential for the innate immune system [205]. The enzyme inactivates autoinducing peptides (AIP) through its enzymatic products [206]. For instance, the inactivation of the AIP signal of S. aureus is caused by oxidation of the C-terminal methionine sulfanyl group of the signal to the corresponding sulfoxide form resulting in the loss of AIP activity [207]. In contrast to various AHL-quenching mechanisms and compounds, only very few AI-2 interfering mechanisms, in particular AI-2 QQ enzymes, were reported so far. E. coli AI-2 kinase LsrK was used in vitro to phosphorylate AI-2, resulting in reduced QS response when added ex vivo to E. coli populations as well as Salmonella typhimurium and V. harveyi cultures [208]. Highly effective inhibition of AI-2 regulated biofilm formation of Klebsiella spp. was demonstrated by the first metagenome-derived AI-2 Quenching enzyme. Here, AI-2 signals were most likely modified by the identified oxidoreductase QQ-2 [209].

$\mathrm{QQ}$ is considered as a natural mechanism evolved either by organisms regulating behaviors via QS for the recycling or clearing of their QS signals or by QQ organisms in the context of a competitive relationship with QS signal-producing organisms [166]. QQ was found to be related to the fine-tuning of QS functions, e.g., clearing of the QS-signal regulated the transfer of the Ti-plasmid in A. tumefaciens, which is crucial for plant infection with crown gall disease [210]. Recycling of QS signals mainly occurs in microorganisms that 
produce QS molecules [166]. For example, in P. aeruginosa, the amidase HacB and PvdQ, and QuiP contribute to AHL recycling by converting AHLs into fatty acids and homoserine lactone (HSL) further assimilated by the bacterium [211]. Likewise, LsrF and LsrG are involved in the degradation of AI-2, thereby terminating the induction of the lsr operon and closing the AI-2 signaling cycle in E. coli [212]. In microorganisms that do not produce QS but are sensitive to the toxicity of QS signals, QQ enzymes play a significant role in detoxification [213]. In Gram-positive Bacillus strains, which communicate via peptides and not AHLs, the AiiA lactonase was identified. Bacillus spp. protect themselves from AHLs by degrading those signaling molecules, which express a bactericidal activity against several Gram-positives [166,214]. Moreover, QS signaling is interfered with by an organism, which does not produce QS signals, but takes advantage of QQ processes [166]. Several eukaryotes, including plants, animals, and hosts of QS-emitting pathogens, express enzymes that can inactivate QS signals [106]. As mentioned above, several studies evaluated the implication of highly conserved paraoxonases (PON1, PON2, and PON3) [173,215,216], for instance, in defense against the pathogen P. aeruginosa. The serum and tracheal epithelial cells of mammals could efficiently inactivate long-chain AHLs of this pathogen [196,197]. Most natural environments harbor diverse microorganisms, and within these communities, bacteria compete with their neighbors for space and resources. Therefore, competitors also evolved several mechanisms to disarm QS systems to avoid bacterial colonization and competence. Inhibitors and antagonists of signal reception [166,217] or enzymatic inactivation were identified among bacteria in natural environments, as already pointed out above [166,218-220]. However, the number of models investigated under natural conditions is low, and efforts towards deciphering $Q Q$ functions in a rational biological context at the cell-, population-, microbiota- and metaorganism level are underrepresented.

Investigations on $\mathrm{QQ}$ also extended to applied domains for developing antibacterial and antidisease strategies that target pathogens and biofilm-forming bacteria in medicine, agronomy, and industry [221]. The development of treatments based on QS interference is largely driven by alternative or complementary approaches to often ineffective antibiotics [222-224]. Conceivable biotechnological applications are manifold, and several examples are published to date, but their application is still only a potential, and studies have to be conducted to direct the potential to real use. In aquaculture, effective alternatives to antibiotics are urgently needed since it is significantly affected by disease outbreaks of often antibiotic-resistant pathogens [225]. Counteracting resistance development, antibiotic administration gets more and more restricted in aquaculture. Known opportunistic pathogens such as Vibrio sp., Aeromonas sp., and Pseudomonas sp. often regulate pathogenesis through QS; consequently, disruption of QS as a new anti-infective approach has great potential for application in aquaculture [226]. Brominated furanones were found to be effective in neutralizing the growth retarding effect of $V$. harveyi strains. They improved the survival and growth of rotifers $[227,228]$ and further protected brine shrimp Artemia franciscana and rainbow trout Oncorhynchus mykiss from pathogenic Vibrio spp. infections $[229,230]$. Several bacterial metabolites were also able to block QS-regulated phenotypes in aquaculture pathogens, among those Shewanella sp. [231,232], Halobacillus salinus [217], and various gut bacteria from marine eukaryotes [233]. By incorporating kojic acid from Aspergillus spp. into a nontoxic paint, bacterial and diatoms colonization and growth were successfully controlled by QS interference in artificial marine settings [234]. In industry, $Q Q$ is applied in wastewater treatment, where membrane bioreactors used for reclamation and desalination of brackish and seawater are constrained by biofouling of the membrane filters [235]. Fouling biofilms formed by Aeromonas hydrophila and P. putida [236] are prevented by small-signal interfering compounds added to antifouling coatings or by immobilizing QQ enzymes or marine organisms engineered to secrete QS inhibitors [237-240]. QQ also finds the way into plant cultivation. Epiphytic bacteria are exploited for controlling diseases by interfering with the QS-regulated virulence of plant pathogens like P. syringae [241,242]. Engineering the production of QQ enzymes into plants and plant-associated microbes is expected to help crop protection, as already 
demonstrated for transgenic tobacco and potato plants, which heterologously expressed Aiia lactonase, resulting in reduced pathogenicity of Erwinia carotovora [190,191]. Finally, QQ is also contemplated to be applied in medicine. The use of garlic as a QS inhibitor against $P$. aeruginosa, which is intrinsically resistant to many antibiotics and causes chronic infections, was demonstrated by Rasmussen et al. [243]. This treatment made the biofilm susceptible to antibiotics, such as tobramycin, and phagocytosis by neutrophils [244]. The first clinical trial on the usage of garlic oil macerate as a QS inhibitor for treating human patients suffering from cystic fibrosis was reported in 2010 [245] and resulted in a slight improvement of lung function, weight, and symptoms score of cystic fibrosis patients. Moreover, Hentzer et al. demonstrated that biofilm formation and virulence factor production in P. aeruginosa was reduced in the presence of synthetic furanones, which have the potential to be incorporated as QS inhibitors on the surfaces of surgical implants and catheters [240,246]. However, they later showed toxic side effects [228].

One of the most important prerequisites to finding effective QQ compounds is their detection with biosensors. AHL and AI-2 reporters were developed throughout by different researchers based on fusing a QS-controlled promoter to a reporter gene [128,144,184,236,247-254]. These biosensors allow for sensitive, quantitative, and real-time detection of QS signals. The reporter strains cannot often produce native QS signals; however, they can respond to exogenous autoinducers, often with a detectable phenotype, such as violacein pigment production in Chromobacterium violaceum CV026 [249] and bioluminescence production in V. harveyi [255] or A. tumefaciens A136 [256]. Most reporters were initially designed to identify new signaling molecules. The QS-promoter is induced by signal molecules possibly present in the environment, leading to the expression of the respective phenotype. By simultaneous addition of defined amounts of promoter-inducing autoinducers in the assay, these biosensors can also be used to identify $Q Q$ compounds, interfering with these signal molecules. In brief, they mimic the natural QS system with easily identifiable phenotypes [257]. Remarkably, there are mostly AHL-QS-based reporters published, which allow the identification of AHL-interfering compounds such as AHL-degrading [218] or -modifying [203] compounds as well as AHL agonists [258] and antagonists [259]. V. harveyi, a reporter for detecting $Q Q$ compounds against Gram-negative and interspecies-specific QS, was developed to identify potential $Q Q$ active compounds by the absence of luminescence [260]. Based on this type of system, a screen will indicate a QS-interfering compound by the disappearance of the reporter signal. One crucial problem of this procedure is that factors other than QQ compounds can also cause a reduction in the signal, e.g., by reducing cell growth. Thus, it can be difficult to obtain reliable information regarding the specificity of a QS-interfering compound that shows additional pleiotropic effects because the decrease in reporter signal is not necessarily proportional to the decrease in monitored out read [243]. Rasmussen et al. designed another type of screening system termed Quorum Sensing Inhibitor Selector (QSIS) to circumvent these problems. The QSIS system is based on E. coli, which comprises an AHL-inducible lethal gene encoding a toxic protein. When the strain senses AHLs in the surrounding environment, the lethal gene is expressed and consequently growth will be inhibited. In contrast, the presence of a QS-interfering compound rescues the bacteria, since expression of the lethal gene is not induced and the bacteria are able to grow [261]. This method of positive selection for growth has proven powerful for isolation of both, synthetic compounds and extracts of plants and fungi with AHL-quenching activities [98]. As already mentioned, in contrast to AHLs, only a few AI-2 QQ compounds were identified to date, probably due to the lack of appropriate reporter systems $[165,262]$. A few reporter systems for the detection of AI-2 like compounds can reportedly be used, in principle, for identification of AI-2 quenching activities. One example is the above mentioned $V$. harveyi-based reporter system with a mutated autoinducer synthase (LuxS) that can be used to detect external accumulation of AI-2, leading to bioluminescence [263]. A second reporter system is based on lacZ fusion to the E. coli AI-2 inducible promoter lsrA [264]. Moreover, reporter strain AI2-QQ.1 was established based on the innovative strategy of Rasmussen and collaborators, which now 
allows identifying for novel, nontoxic biomolecules interfering with AI-2-based QS using positive selection [254]. Nowadays, bacterial isolates, extracts, and metagenomic and synthetic libraries can be rapidly screened for QQ compounds with such biosensors, and the compounds further tested for their application. However, finding new QQ strategies and their effective application in controlling pathogens and bacterial biofilms raised questions about the potential for resistance development against QQ agents. This has become a controversial discussion [265]. The lack of direct effects on the viability of bacteria resulted in the hypothesis that selection for and the appearance of resistant mutants might be less frequent than traditional antibiotic treatment. However, Defoirdt et al. controverted the assumption that QS disruption is not leading to resistance and suggested that the fitness of bacteria can be affected through variability in QS core genes [266]. Additionally, a study has demonstrated that $Q Q$ compounds can indeed generate $Q Q$ resistance in P. aeruginosa [267]. Bacteria could easily escape from $Q Q$ approaches by altering the expression of core genes in the targeted QS signaling pathway, such as the genes involved in the signal synthesis, detection, and transduction. It is thus likely that bacteria may develop resistance to QQ; however, it was suggested that the chances of developing resistance are smaller than for conventional antibiotics [225].

In conclusion, QQ strategies have evolved in many pro-and eukaryotes as a mechanism for recycling or clearing their own synthesized QS signals or as a competitive strategy against $\mathrm{QS}$ signal-producing organisms. Moreover, $\mathrm{QQ}$ might become an effective alternative to combat infections and bacterial biofilms, either as single agents or in combination with antibiotics or other alternative strategies. However, future studies should focus on the underlying QQ mechanisms at a molecular level, their biological role in microbial communities, and their use as antibacterial treatment under realistic conditions to exclude toxic side effects.

\subsection{Microbe-Host Interactions}

Half a century ago, Lynn Margulis first recognized the importance of bacteria in the evolution of higher organisms [268-271]. In 2007, the term "hologenome" was introduced by Ilana Zilber-Rosenberg and Eugene Rosenberg to describe the sum of the host genome and associated microbial genomes [272-274]. This settled the base for a still ongoing paradigm shift in biology. Nowadays, a new conceptual framework-the holobiont/metaorganism concept-is established, considering a holobiont/metaorganism as the sum of a multicellular host and its associated species (as illustrated in Figure 7) [275]. The holobiont theory considers all associated species irrespective of their type of association (transient or permanent) or their function. The metaorganism concept focuses on the function and contribution (beneficial or detrimental) of the host-associated microbiota in a given environment, which depend on the identity, abundance, and activity of the microbes (in the following, the term "metaorganism" is primarily used) $[272,274,276]$. The growing awareness that multicellular organisms cannot be considered in isolation but only in the interdependence with their associated microbes led to two important insights. Firstly, the health and fitness of a host appear to be fundamentally multiorganismal, where any disturbance within the complex partnership can have drastic consequences for the members' health. Secondly, host and microbes intensively interact and coevolve [277-279] (as illustrated in Figure 7). Several studies already indicate that a specific host-associated microbiota contributes to host metabolism, development, organ morphogenesis, pathogen protection and immunity, behavior, environmental sensing and adaptation, developmental transitions, and reproduction [278,280-294] (as illustrated in Figure 7). A specific microbe or consortia function is not static because it depends on the host's developmental stage, age, reproductive state, or physiological condition $[276,278,295]$. The vast contribution of the microbiota to the fitness of its host was unraveled mainly in the last decade. Protection against pathogens and provision of essential nutrients were identified as the most general and important contributions of the associated microbiota to the host's health. In corals, commensal bacteria protect against the bleaching pathogen $V$. shiloi [296] and produce 
inhibitors to reduce colonization by pathogens on coral mucus [297]. Several experiments further reported that sterile animals are considerably more sensitive to infection and death following administration of a pathogen than conventional animals, e.g., shown for infection of guinea pigs with Shigella flexneri [298], mice with V. cholera [299], and rabbits with Bacteroides vulgatus [300]. Likewise, in humans, the normal microbiota was shown to protect against infection by pathogens in the oral cavity, the intestine, the skin, and the vaginal epithelium [301-304]. Representatives of the genera Pseudomonas, Flavobacteria, and Bacillus can protect plants from phytopathogens through direct interaction with the pathogen or by inducing systemic resistance in plant hosts [305,306]. In general, microorganisms residing in a plant's rhizosphere are essential for plant growth promotion, disease suppression, removing toxic compounds, and assimilating nutrients to plants [307]. Moreover, utilizing such beneficial microbes for crop productivity presents an efficient way to modulate the crop yield and productivity by maintaining the health status and quality of the plants [308-310]. The utilization of beneficial microbe-plant interactions is now turning into the standard against the chemical-based and synthetic pesticides and fertilizers in the agriculture industry $[307,311,312]$. Moreover, the contribution of the microbiota to the nutrition of the hosts is known for many years. For example, chemoautotrophic bacterial symbionts, like sulfur-oxidizing bacteria, synthesize organic matter from $\mathrm{CO}_{2}$ and are the primary source of nutrition for their animal host [313]. In turn, the host, like clams and mussels, provides its symbionts a habitat, in which they have access to the substrates of chemoautotrophy $\left(\mathrm{O}_{2}, \mathrm{CO}_{2}\right.$, and reduced inorganic compounds such as $\left.\mathrm{H}_{2} \mathrm{~S}\right)$ [314]. In humans, the gut microbiota is a complex ecosystem that plays an essential role in the catabolism of dietary fiber, production of vitamins and amino acids, and detoxification of harmful chemicals $[315,316]$. In recent years, several studies further demonstrated that the microbiome also contributes to the development of a variety of tissues, functions, and organs [273,317]. An illustration of bacteria-dependent development can be seen for many green algae, which develop abnormally in the absence of bacteria [318]. For example, the marine green alga Ulva lactuca loses its typical leafy morphology in axenic culture and develops into pincushion-like colonies. However, these abnormal algal colonies can be restored to their typical morphology by recolonization with appropriate marine bacteria [319]. Also, gut bacteria were shown to shape the tissues, cells, and molecular profile of the mammalian gastrointestinal immune system during development [320]. Microbes interact with the host cells through adhesive molecules on their surface, thus promoting interaction with host cell receptors and triggering host responses among those immune responses and metabolic and behavioral reactions [321]. For instance, first experiments with mice demonstrated that gut microbiota affects the brain and, consequently, behavior [322]. It is most likely that during evolution, gut microbiota colonization became integrated into the programming of brain development affecting the central nervous system and behavior [323]. Bacteria communicate with the brain via changing levels of dietary metabolites and hormones [324]. The gut microbiota can be a key regulator of mood, cognition, pain, and obesity [325]. Understanding the microbiota-gut-brain axis can give new insights into individual variations in cognition, personality, mood, sleep, and eating behavior and how microbes contribute to a range of neuropsychiatric diseases ranging from affective disorders to autism and schizophrenia. Understanding such complex host-microbe interactions can thus be a key for developing therapeutics against diseases, but also finding pre- and probiotics to prevent infections and disorders in the future [326]. Besides cooperation between microbiota and host, there are numerous examples of interactions among different species of microorganisms within a metaorganism, like cross-feeding between microbes in the mucus of coral holobionts [327] or sharing of "public goods" in microbial biofilms on the outer surface of animals or plants as well as the digestive tract of animals [328], ultimately resulting in a fitness benefit for the metaorganism as a whole. Some cooperative microbial interactions are so called byproduct mutualistic interactions. For instance, the host benefits from byproducts of a bacterial metabolism as known for short-chain fatty acids produced by bacteria in the large intestine of mammals during anaerobic metabolism $[329,330]$. The 
aphid-Buchnera symbiosis exemplifies that benefits for the host in the end also possess an advantage for the symbiont, and thus for the whole metaorganism, since energy-costly overproduction of amino acids by the endosymbiont, which are essential to the insect host, finally configure the environment for the endosymbiont [331,332]. The manifold examples of cooperation do not contradict the competition existing within the metaorganism among different microbial community members, as discussed above (see Section 2.4).

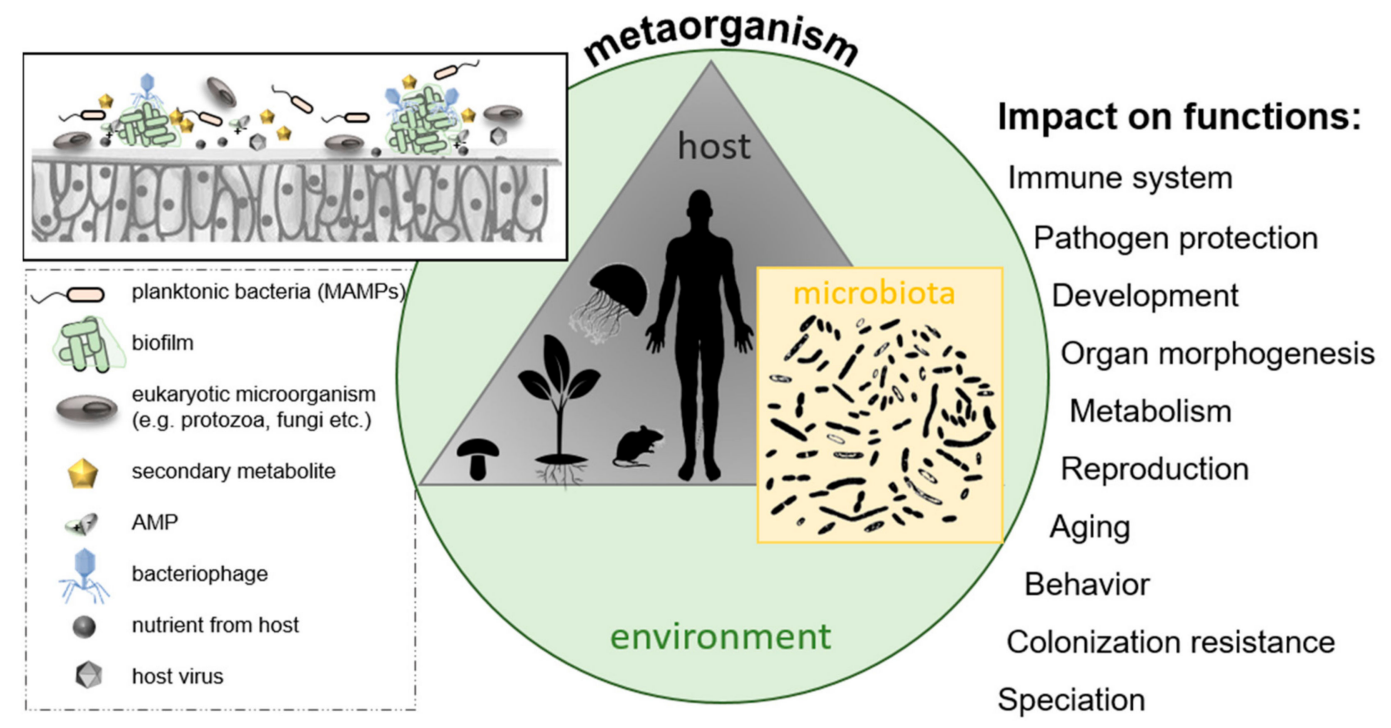

Figure 7. The metaorganism concept; a metaorganism consists of a multicellular host and its associated microbiota located in a specific environment. Selected factors are presented that might influence bacterial colonization of host surfaces, ultimately affecting various host functions.

The metaorganism concept leads to the assumption that the evolution of multicellular host organisms primarily occurred by cooperation with their associated microbiota. Cooperation among microbes and between microbes and their host coevolved over millions of years, exemplified by arbuscular mycorrhizal fungi and roots of vascular plants (ca. 400 million years ago) [333]. Here, fungi of the phylum Glomeromycota penetrate the cortical cells of the roots of a vascular plant forming arbuscules. The fungus enables its plant host to capture nutrients such as phosphorus, sulfur, nitrogen, and micronutrients from the soil. The arbuscular mycorrhizal symbiosis most likely played a crucial role in the evolution of vascular plants and their initial colonization on land. Arbuscular mycorrhizal symbiosis is presumed to be the most prevalent known plant symbiosis and is found in $80 \%$ of vascular plant families [334]. Evolved mutualistic relationships are further known for endosymbiotic algae and corals (ca. 240 million years ago) [335], ruminants and their microbiota (ca. 60 million years ago) [336], and the great apes and gut microbiota (15-20 million years ago) $[337,338]$. The gut microbiome also demonstrates evolution by acquiring a microbiota in ruminants and termites, where the microbes degrade cellulose of plant material, enabling the host to metabolize those nutrients [339,340]. One of the major advantages of microbiota acquisition is that it allows for rapid adaptation to new environments. Such an example is shown for the bacterium Burkholderia, which is resistant to an insecticide, and further led to the resistance of the host insect to the insecticide [341]. The evolution of metaorganisms can also be acquired by the horizontal transfer of microbial genetic information to the host chromosome [342]. There are numerous known examples of horizontal gene transfer (HGT) between symbionts and their hosts, e.g., transfer of biosynthetic genes for carotenoid production from a fungus to aphids [343], gene transfer from the endosymbiont Wolbachia to the arthropod host [344], and transfer of the long interspersed nuclear element (LINE-1) from human to the pathogen Neisseria gonorrhoeae [345]. 
In summary, all animals and plants are inhabited by microbial organisms, which influence the health and fitness of their hosts, ultimately forming a metaorganism harboring complex interactions among microbial community members and between the microbes and their host. Research on host-microbe interactions became an emerging cross-disciplinary field. A diverse and complex microbiome confers immunological, metabolic, and behavioral benefits; its disturbance can contribute to disease development. However, the molecular and cellular mechanisms controlling interactions within the metaorganisms are poorly understood, and many key interactions between the associated organisms remain unknown. Future studies should focus particularly on the functional consequences of the interactions and the impact of the microbiota on the host's life history and evolutionary fitness.

\section{Methods for Studying Microbial Interactions}

Microorganisms play a vital role in various ecosystems, and characterizing interactions between them is an essential step towards understanding the organization and function of microbial communities [346]. A key for understanding microbial interactions is the continual development of cutting-edge methods and controlled experimental platforms. The fact that the vast majority (95-99\%) of microbes were not cultivated points to the urgent need for cultivation-independent approaches and methods, which are summarized as "metagenomics" [347]. The term metagenomics was first used by Jo Handelsman in 1998 [348]. Metagenomics is defined as the genomic analysis of an assemblage of organisms in a given habitat by direct extraction and cloning of the whole DNA [349]. Consequently, metagenomics can unlock the massive uncultured microbial diversity present in an environment. Metagenomics studies identified many novel microbial genes coding for metabolic pathways, such as energy acquisition, carbon and nitrogen metabolism, and novel genes, particles, and compounds applicable to biotechnology [350-354]. Metagenomics allows the investigation of microbes in their natural environments and complex communities associated with abiotic and biotic surfaces as in metaorganisms [355]. There are two basic types of metagenomics studies: (i) sequence-based metagenomics that involves sequencing and analysis of DNA from environmental samples, and (ii) function-based metagenomics that comprise screening for a particular function or activity [356]. Sequence-based metagenomics can be used to assemble genomes, identify genes, find complete metabolic pathways, and analyze microbial diversity and abundance, providing information about the ecology of the microbes in the community and within a metaorganism [357-362]. Functional metagenomics is a powerful experimental approach for studying gene function, starting from the extracted DNA of mixed microbial populations or a whole metaorganism. A functional approach relies on the construction and screening of metagenomic libraries-physical libraries that contain DNA cloned from environmental metagenomes into vector backbones. Cosmid- or fosmid-based libraries are often used due to their large and consistent insert size and high cloning efficiency [350-353,356,363]. Moreover, metagenomics led to the discovery and characterization of a wide range of biocatalysts and novel compounds for clinical, industrial, and biotechnological applications. For instance, the investigation of symbiotic bacteria by metagenomics led to the identification of a rare type I polyketide synthase, allowing the generation of novel antitumor compounds [364]. Analysis of metagenomic libraries revealed a high frequency of novel antibiotics present in soil [365]. A novel antibiotic, palmitoylputrescine, was found in the tropical plant (bromeliads) tank water, and a novel bacterial mechanism for inactivation of tetracycline was found in the oral metagenome [366]. Metagenomics further identified novel xenobiotic degradation pathways used by prokaryotes in the environment [367], which can be used in biotechnology. One of the main areas of metagenomic research from the beginning was discovering novel biocatalysts, including esterases, nitrile hydratases, alcohol reductases, amidases, cellulases, amylases, glycogen-branching enzymes, and pectate lyases [368-374].

Besides metagenomics, advances in sequencing and "omic" technologies improved effectively tracking microbial community composition and the metabolic activity of microbes, 
further allowing for correlations on microbial functions [375]. Sequencing RNA from both prokaryotic and eukaryotic cells simultaneously can reveal how the host and its associated microbiota interact at the gene expression level [376]. Additional in situ methods can also help to capture microbial interactions [377]. Techniques for quantitative imaging of labeled bacteria and their surroundings, including fluorescence in situ hybridization labeling of bacteria and noninvasive imaging of extracellular milieu components, add a critical spatial dimension to microbial studies [377,378]. Metabolic labeling enables even tracking microbial activity [379]. Nowadays, synthetic approaches also help to explore the complexity of microbial interactions [380,381]. On the one hand, synthetic microbial communities offer reduced complexity and can more easily be mathematically modeled [382]. On the other hand, advances in synthetic biology enabled the engineering of microbes with genetically defined properties [383]. These engineered bacteria were combined with artificial environments to study microbial interactions in response to environmental cues. Experimentally, microchamber-based methods were developed to mimic the natural environment, exemplified in a microfluidic assay to assess dynamic root-microbe interactions [384] and in an in situ chemotaxis assay (ISCA) to study marine microbial behaviors at spatially relevant scales [385]. However, it should not be neglected that understanding microbial community interactions, particularly all the complex interactions that take place in metaorganisms, also rely on cultivation-dependent approaches [295]. The cultivation of bacteria is highly biased toward a few phylogenetic groups. New cultivation concepts were and will still be developed based on an improved understanding of the ecology of previously uncultivable bacteria. Here, media that mimic the natural types and concentrations of substrates and nutrients, high-throughput cultivation techniques, and approaches that exploit biofilm formation and bacterial interactions crucially improved cultivation techniques [386]. Metagenomics and single-cell genomics can further reveal unknown metabolic features, the information needed for improved cultivation or even cocultivation of microbes [387]. Notably, studies on host-microbe interactions rely on the combination of largely (gnotobiotic) or completely (axenic) germ-free hosts with cultured microbial isolates to gain detailed insights into the contributions of microbes to metaorganism function [284,388]. Such recolonization experiments enable assigning a function to specific microbes $[276,388,389]$ as well as to determine the colonization dynamics of microbes [388,390] and to elucidate bacteriabacteria interactions $[284,391]$. All the presented technologies can provide insights into the complexities of microbial communities, the function of microbes, and the interaction among these microbes with their hosts. Despite the remarkable advances in the study of microbial communities, we are still far from understanding the complete picture. Moving beyond purely observational approaches, experimental and computational methods that facilitate the interpretation of microbe interactions with each other and their communities must be enhanced. Computational modeling and analysis tools need to be developed and implemented to investigate environmental correlations and to understand microbial dependencies and their coevolution [392].

Besides understanding microbial interactions, research also focused on investigations to use microbial consortia in biotechnology processes, including fermentation, waste treatment, and agriculture, for millennia [393]. However, only an improved understanding of natural microbial ecosystems and the development of new tools to construct synthetic and engineered consortia vastly expanded the possibilities of using microbial consortia for diverse applications, including bioproduction of medicines, biofuels, and biomaterials [394]. Microbial communities comprising several partners can often jointly perform complex processes more efficiently, yielding the desired product at an increased rate than that of a single species [395]. Interactions between the microbial partners in these mixed communities are expected to significantly impact the microorganisms' combined performance and the bioprocess as a whole. Commensal or mutualistic interactions among microbial members of a consortium can significantly enhance the product outcome of the bioprocess, ensuring their industrial application and long-term stability [395]. Beyond being simply positive or negative, beneficial or inhibitory, microbial interactions can involve a diverse set 
of mechanisms, dependencies, and dynamical properties. This complexity of interactions must be studied by further developing cutting-edge techniques that enable the elucidation of multidimensional and dynamic relationships among microbes and between microbes and the host.

\section{Conclusions}

Microorganisms live in close contact with each other and to multicellular hosts, usually including many species. Additionally, microbes are exposed to variations in the environment, which in turn affect the interactions. Microbial interactions are thus highly complex, and many mechanisms and molecules are involved [5]. Studies on microbial interactions led to significant findings in microbiology, botany, zoology, and ecology. Research on microbial interactions also enabled discoveries for clinical, industrial, and biotechnological applications, e.g., antimicrobial drug development based on natural products like QS interfering compounds. Further, the realization that a germ-free multicellular organism does not exist in nature led to the holobiont/metaorganism concept and a paradigm shift in life science. It is now believed that it would be impossible to fully understand a multicellular organism without considering its associated microbes, but it is possible to study microbes without knowledge of animals and plants. There is still a lot to understand about the molecular mechanisms and languages used by microorganisms and the molecules and signals involved in microbial interactions, in particular with the host. The development and refinement of tools and methods, including in vitro and in vivo models, are urgently needed to understand better and characterize microbial interactions with more molecular details. Elucidating complex microbial interactions in an ever-changing environment in nature is probably the most challenging endeavor.

Funding: This research was funded by VOLKSWAGENSTIFTUNG, grant number 95546.

Institutional Review Board Statement: Not applicable.

Informed Consent Statement: Not applicable.

Data Availability Statement: Not applicable.

Acknowledgments: The work was facilitated by Kiel University, in particular by R. A. Schmitz-Streit at the Institute of General Microbiology.

Conflicts of Interest: The author declares no conflict of interest.

\section{References}

1. Flemming, H.-C.; Stefan, W. Bacteria and archaea on Earth and their abundance in biofilms. Nat. Rev. Microbiol. 2019, 17, 247-260. [CrossRef]

2. Bar-On, Y.M.; Phillips, R.; Milo, R. The biomass distribution on Earth. Proc. Natl. Acad. Sci. USA 2018, 115, 6506-6511. [CrossRef]

3. Davey, M.E.; O’Toole, G.A. Microbial Biofilms: From Ecology to Molecular Genetics. Microbiol. Mol. Biol. Rev. 2000, 64, 847-867. [CrossRef]

4. Dunny, G.M.; Brickman, T.J.; Dworkin, M. Multicellular behavior in bacteria: Communication, cooperation, competition and cheating. BioEssays 2008, 30, 296-298. [CrossRef] [PubMed]

5. Braga, R.M.; Dourado, M.N.; Araújo, W.L. Microbial interactions: Ecology in a molecular perspective. Braz. J. Microbiol. 2016, 47, 86-98. [CrossRef]

6. DiCenzo, G.C.; Zamani, M.; Checcucci, A.; Fondi, M.; Griffitts, J.S.; Finan, T.M.; Mengoni, A. Multidisciplinary approaches for studying rhizobium-legume symbioses. Can. J. Microbiol. 2019, 65, 1-33. [CrossRef] [PubMed]

7. Morowitz, M.J.; Carlisle, E.M.; Alverdy, J.C. Contributions of Intestinal Bacteria to Nutrition and Metabolism in the Critically Ill. Surg. Clin. N. Am. 2011, 91, 771-785. [CrossRef] [PubMed]

8. Sender, R.; Fuchs, S.; Milo, R. Revised Estimates for the Number of Human and Bacteria Cells in the Body. PLoS Biol. 2016, 14, e1002533. [CrossRef]

9. Wang, B.; Yao, M.; Lv, L.; Ling, Z.; Li, L. The Human Microbiota in Health and Disease. Engineering 2017, 3, 71-82. [CrossRef]

10. Pilo, P.; Frey, J. Pathogenicity, population genetics and dissemination of Bacillus anthracis. Infect. Genet. Evol. 2018, 64, 115-125. [CrossRef]

11. Lantos, P.M. Chronic Lyme Disease. Infect. Dis. Clin. N. Am. 2015, 29, 325-340. [CrossRef] 
12. Young, K.T.; Davis, L.M.; DiRita, V.J. Campylobacter jejuni: Molecular biology and pathogenesis. Nat. Rev. Genet. 2007, 5, 665-679. [CrossRef]

13. Duell, B.L.; Su, Y.-C.; Riesbeck, K. Host-pathogen interactions of nontypeableHaemophilus influenzae: From commensal to pathogen. FEBS Lett. 2016, 590, 3840-3853. [CrossRef]

14. Cordero, O.X.; Datta, M.S. Microbial interactions and community assembly at microscales. Curr. Opin. Microbiol. 2016, 31, 227-234. [CrossRef]

15. Atkinson, N.J.; Lilley, C.J.; Urwin, P.E. Identification of Genes Involved in the Response of Arabidopsis to Simultaneous Biotic and Abiotic Stresses. Plant Physiol. 2013, 162, 2028-2041. [CrossRef] [PubMed]

16. Barton, L.L.; Northup, D.E. Microbial Ecology; Wiley-Blackwell: Hoboken, NJ, USA, 2011.

17. Scott, K.P.; Gratz, S.W.; Sheridan, P.O.; Flint, H.J.; Duncan, S.H. The influence of diet on the gut microbiota. Pharmacol. Res. 2013, 69, 52-60. [CrossRef] [PubMed]

18. Daims, H.; Lücker, S.; Wagner, M. A New Perspective on Microbes Formerly Known as Nitrite-Oxidizing Bacteria. Trends Microbiol. 2016, 24, 699-712. [CrossRef] [PubMed]

19. Jurkevitch, É; Jacquet, S. Bdellovibrio and Like Organisms: Outstanding Predators! Med. Sci. 2017, 33, 519-527.

20. de Boer, W.; Folman, L.B.; Summerbell, R.C.; Boddy, L. Living in a fungal world: Impact of fungi on soil bacterial niche development. FEMS Microbiol. Rev. 2005, 29, 795-811. [CrossRef]

21. Long, R.A.; Azam, F. Antagonistic Interactions among Marine Pelagic Bacteria. Appl. Environ. Microbiol. 2001, 67, 4975-4983. [CrossRef] [PubMed]

22. Tang, L. Microbial interactions. Nat. Chem. Biol. 2018, 16, 19. [CrossRef] [PubMed]

23. Hibbing, M.; Fuqua, C.; Parsek, M.R.; Peterson, S.B. Bacterial competition: Surviving and thriving in the microbial jungle. Nat. Rev. Genet. 2009, 8, 15-25. [CrossRef] [PubMed]

24. Zeilinger-Migsich, S.; Mukherjee, P.K. Fungus-Fungus Interactions. Open Mycol. J. 2014, 8, 27. [CrossRef]

25. Partida-Martinez, L.P.; Groth, I.; Schmitt, I.; Richter, W.; Roth, M.; Hertweck, C. Burkholderia Rhizoxinica Sp. Nov. And Burkholderia Endofungorum Sp. Nov., Bacterial Endosymbionts of the Plant-Pathogenic Fungus Rhizopus Microsporus. Int. J. Syst. Evol. Microbiol. 2007, 57, 2583-2590. [CrossRef] [PubMed]

26. Ram, R.M.; Keswani, C.; Bisen, K.; Tripathi, R.; Singh, S.P.; Singh, H.B. Biocontrol Technology: Eco-Friendly Approaches for Sustainable Agriculture. Omics Technol. Bio-Eng. 2018, 2, 177-190.

27. Singh, A.; Sarma, B.K.; Singh, H.B.; Upadhyay, R.S. Trichoderma: A Silent Worker of Plant Rhizosphere. Biotechnol. Biol. Trichoderma 2014, 533-542.

28. Macheleidt, J.; Mattern, D.J.; Fischer, J.; Netzker, T.; Weber, J.; Schroeckh, V.; Valiante, V.; Brakhage, A.A. Regulation and Role of Fungal Secondary Metabolites. Annu. Rev. Genet. 2016, 50, 371-392. [CrossRef]

29. Brakhage, A.A. Regulation of fungal secondary metabolism. Nat. Rev. Genet. 2012, 11, 21-32. [CrossRef]

30. Nützmann, H.-W.; Reyes-Dominguez, Y.; Scherlach, K.; Schroeckh, V.; Horn, F.; Gacek, A.; Schümann, J.; Hertweck, C.; Strauss, J.; Brakhage, A.A. Bacteria-induced natural product formation in the fungus Aspergillus nidulans requires Saga/Ada-mediated histone acetylation. Proc. Natl. Acad. Sci. USA 2011, 108, 14282-14287. [CrossRef]

31. Hug, J.J.; Bader, C.D.; Remškar, M.; Cirnski, K.; Müller, R. Concepts and Methods to Access Novel Antibiotics from Actinomycetes. Antibiotics 2018, 7, 44. [CrossRef]

32. Barka, E.A.; Vatsa, P.; Sanchez, L.; Gaveau-Vaillant, N.; Jacquard, C.; Klenk, H.; Clément, C.; Ouhdouch, Y.; van Wezel, G.P. Taxonomy, Physiology, and Natural Products of Actinobacteria. Microbiol. Mol. Biol. Rev. 2016, 80, 1-43. [CrossRef] [PubMed]

33. Puppi, G.; Azcón, R.; Höflich, G. Management of Positive Interactions of Arbuscular Mycorrhizal Fungi with Essential Groups of Soil Microorganisms. In Impact of Arbuscular Mycorrhizas on Sustainable Agriculture and Natural Ecosystems; Springer: Berlin/Heidelberg, Germany, 1994; pp. 201-215.

34. Johansson, J.F.; Paul, L.R.; Finlay, R.D. Microbial interactions in the mycorrhizosphere and their significance for sustainable agriculture. FEMS Microbiol. Ecol. 2004, 48, 1-13. [CrossRef]

35. Deveau, A.; Bonito, G.; Uehling, J.; Paoletti, M.; Becker, M.; Bindschedler, S.; Hacquard, S.; Hervé, V.; Labbé, J.; Lastovetsky, O.A.; et al. Bacterial-fungal interactions: Ecology, mechanisms and challenges. FEMS Microbiol. Rev. 2018, 42, 335-352. [CrossRef] [PubMed]

36. Wargo, M.J.; Hogan, D.A. Fungal—Bacterial interactions: A mixed bag of mingling microbes. Curr. Opin. Microbiol. 2006, 9, 359-364. [CrossRef] [PubMed]

37. Brocks, J.J.; Logan, G.A.; Buick, R.; Summons, R.E. Archean Molecular Fossils and the Early Rise of Eukaryotes. Science 1999, 285, 1033-1036. [CrossRef]

38. Wrede, C.; Dreier, A.; Kokoschka, S.; Hoppert, M. Archaea in Symbioses. Archaea 2012, 2012, 1-11. [CrossRef]

39. Horz, H.P.; Conrads, G. The Discussion Goes On: What Is the Role of Euryarchaeota in Humans? Archaea 2010. [CrossRef]

40. Eckburg, P.B.; Lepp, P.W.; Relman, D.A. Archaea and Their Potential Role in Human Disease. Infect. Immun. 2003, 71, 591-596. [CrossRef]

41. Burghardt, T.; Junglas, B.; Siedler, F.; Wirth, R.; Huber, H.; Rachel, R. The interaction of Nanoarchaeum equitans with Ignicoccus hospitalis: Proteins in the contact site between two cells. Biochem. Soc. Trans. 2009, 37, 127-132. [CrossRef]

42. Küper, U.; Meyer, C.; Müller, V.; Rachel, R.; Huber, H. Energized outer membrane and spatial separation of metabolic processes in the hyperthermophilic Archaeon Ignicoccus hospitalis. Proc. Natl. Acad. Sci. USA 2010, 107, 3152-3156. [CrossRef] [PubMed] 
43. Podar, M.; Anderson, I.; Makarova, K.S.; Elkins, J.G.; Ivanova, N.; Wall, M.A.; Lykidis, A.; Mavromatis, K.; Sun, H.; Hudson, M.E.; et al. A genomic analysis of the archaeal system Ignicoccus hospitalis-Nanoarchaeum equitans. Genome Biol. 2008, 9, 1-18. [CrossRef]

44. Koerdt, A.; Gödeke, J.; Berger, J.; Thormann, K.M.; Albers, S.-V. Crenarchaeal Biofilm Formation under Extreme Conditions. PLoS ONE 2010, 5, e14104. [CrossRef]

45. Bryant, M.P.; Wolin, E.A.; Wolin, M.J.; Wolfe, R.S. Methanobacillus omelianskii, a symbiotic association of two species of bacteria. Arch. Microbiol. 1967, 59, 20-31. [CrossRef]

46. Reddy, C.A.; Bryant, M.P.; Wolin, M.J. Characteristics of S organism isolated from Methanobacillus omelianskii. J. Bacteriol. 1972, 109, 539-545. [CrossRef]

47. Eichler, B.; Schink, B. Oxidation of primary aliphatic alcohols by Acetobacterium carbinolicum sp. nov., a homoacetogenic anaerobe. Arch. Microbiol. 1984, 140, 147-152. [CrossRef]

48. Wallrabenstein, C.; Hauschild, E.; Schink, B. Syntrophobacter Pfennigii Sp. Nov., New Syntrophically Propionate-Oxidizing Anaerobe Growing in Pure Culture with Propionate and Sulfate. Arch. Microbiol. 1995, 164, 346-352. [CrossRef]

49. Bryant, M.P.; Campbell, L.L.; Reddy, C.A.; Crabill, M.R. Growth of Desulfovibrio in Lactate or Ethanol Media Low in Sulfate in Association with H2-Utilizing Methanogenic Bacteria. Appl. Environ. Microbiol. 1977, 33, 1162-1169. [CrossRef] [PubMed]

50. Ben-Bassat, A.; Lamed, R.; Zeikus, J.G. Ethanol Production by Thermophilic Bacteria: Metabolic Control of End Product Formation in Thermoanaerobium Brockii. J. Bacteriol. 1981, 146, 192-199. [CrossRef] [PubMed]

51. Klemps, R.; Cypionka, H.; Widdel, F.; Pfennig, N. Growth with hydrogen, and further physiological characteristics of Desulfotomaculum species. Arch. Microbiol. 1985, 143, 203-208. [CrossRef]

52. Imachi, H.; Sekiguchi, Y.; Kamagata, Y.; Hanada, S.; Ohashi, A.; Harada, H. Pelotomaculum Thermopropionicum Gen. Nov., Sp. Nov., an Anaerobic, Thermophilic, Syntrophic Propionate-Oxidizing Bacterium. Int. J. Syst. Evol. Microbiol. 2002, 52, $1729-1735$. [PubMed]

53. Cui, M.; Ma, A.; Qi, H.; Zhuang, X.; Zhuang, G. Anaerobic Oxidation of Methane: An “Active" Microbial Process. Microbiologyopen 2015, 4, 1-11. [CrossRef]

54. Muller, F.; Brissac, T.; Le Bris, N.; Felbeck, H.; Gros, O. First description of giant Archaea (Thaumarchaeota) associated with putative bacterial ectosymbionts in a sulfidic marine habitat. Environ. Microbiol. 2010, 12, 2371-2383. [CrossRef]

55. Enzmann, F.; Mayer, F.; Rother, M.; Holtmann, D. Methanogens: Biochemical background and biotechnological applications. AMB Express 2018, 8, 1-22. [CrossRef] [PubMed]

56. Eckburg, P.B.; Bik, E.M.; Bernstein, C.N.; Purdom, E.; Dethlefsen, L.; Sargent, M.; Gill, S.R.; Nelson, K.E.; Relman, D.A. Diversity of the Human Intestinal Microbial Flora. Science 2005, 308, 1635-1638. [CrossRef] [PubMed]

57. Samuel, B.S.; Gordon, J.I. A humanized gnotobiotic mouse model of host-archaeal-bacterial mutualism. Proc. Natl. Acad. Sci. USA 2006, 103, 10011-10016. [CrossRef]

58. Hackstein, J.H.; Akhmanova, A.; Boxma, B.; Harhangi, H.R.; Voncken, F.G. Hydrogenosomes: Eukaryotic adaptations to anaerobic environments. Trends Microbiol. 1999, 7, 441-447. [CrossRef]

59. Pape, T.; Hoffmann, F.; Quéric, N.-V.; von Juterzenka, K.; Reitner, J.; Michaelis, W. Dense populations of Archaea associated with the demosponge Tentorium semisuberites Schmidt, 1870 from Arctic deep-waters. Polar Biol. 2006, 29, 662-667. [CrossRef]

60. Turque, A.S.; Batista, D.; Silveira, C.B.; Cardoso, A.; Vieira, R.P.; Moraes, F.C.; Clementino, M.M.; Albano, R.; Paranhos, R.; Martins, O.B.; et al. Environmental Shaping of Sponge Associated Archaeal Communities. PLoS ONE 2010, 5, e15774. [CrossRef]

61. Han, M.; Liu, F.; Zhang, F.; Li, Z.; Lin, H. Bacterial and Archaeal Symbionts in the South China Sea Sponge Phakellia fusca: Community Structure, Relative Abundance, and Ammonia-Oxidizing Populations. Mar. Biotechnol. 2012, 14, 701-713. [CrossRef]

62. Radax, R.; Rattei, T.; Lanzen, A.; Bayer, C.; Rapp, H.T.; Urich, T.; Schleper, C. Metatranscriptomics of the marine sponge Geodia barretti: Tackling phylogeny and function of its microbial community. Environ. Microbiol. 2012, 14, 1308-1324. [CrossRef] [PubMed]

63. Guttman, B.S. Virus. In Encyclopedia of Genetics; Brenner, S., Miller, J.H., Eds.; Academic Press: Cambridge, MA, USA, 2001; pp. 2108-2114.

64. Domingo-Calap, P.; Delgado-Martínez, J. Bacteriophages: Protagonists of a Post-Antibiotic Era. Antibiotics 2018, 7, 66. [CrossRef] [PubMed]

65. Clokie, M.R.J.; Millard, A.D.; Letarov, A.V.; Heaphy, S. Phages in nature. Bacteriophage 2011, 1, 31-45. [CrossRef] [PubMed]

66. Ackermann, H.-W. Phage Classification and Characterization. In Methods in Molecular Biology; Springer Science and Business Media LLC.: Berlin/Heidelberg, Germany, 2009; Volume 501, pp. 127-140.

67. Mann, N.H. The Third Age of Phage. PLoS Biol. 2005, 3, e182. [CrossRef]

68. Hobbs, Z.; Abedon, S.T. Diversity of phage infection types and associated terminology: The problem with 'Lytic or lysogenic'. FEMS Microbiol. Lett. 2016, 363, fnw047. [CrossRef]

69. Stone, E.; Campbell, K.; Grant, I.; McAuliffe, O. Understanding and Exploiting Phage-Host Interactions. Viruses 2019, 11, 567. [CrossRef] [PubMed]

70. Silva, J.B.; Storms, Z.; Sauvageau, D. Host Receptors for Bacteriophage Adsorption. FEMS Microbiol. Lett. 2016, 363. [CrossRef]

71. Keen, E.C.; Dantas, G. Close Encounters of Three Kinds: Bacteriophages, Commensal Bacteria, and Host Immunity. Trends Microbiol. 2018, 26, 943-954. [CrossRef] [PubMed] 
72. Feiner, R.; Argov, T.; Rabinovich, L.; Sigal, N.; Borovok, I.; Herskovits, A.A. A new perspective on lysogeny: Prophages as active regulatory switches of bacteria. Nat. Rev. Genet. 2015, 13, 641-650. [CrossRef] [PubMed]

73. Koskella, B.; Brockhurst, M.A. Bacteria-phage coevolution as a driver of ecological and evolutionary processes in microbial communities. FEMS Microbiol. Rev. 2014, 38, 916-931. [CrossRef]

74. Schneider, C.L. Bacteriophage-Mediated Horizontal Gene Transfer: Transduction; Harper, D., Abedon, S., Burrowes, B., McConville, M., Eds.; Springer: Cham, Switzerland, 2017.

75. Gogokhia, L.; Buhrke, K.; Bell, R.; Hoffman, B.; Brown, D.G.; Hanke-Gogokhia, C.; Ajami, N.J.; Wong, M.C.; Ghazaryan, A.; Valentine, J.F; ; et al. Expansion of Bacteriophages Is Linked to Aggravated Intestinal Inflammation and Colitis. Cell Host Microbe 2019, 25, 285-299. [CrossRef]

76. Laxminarayan, R.; Duse, A.; Wattal, C.; Zaidi, A.K.M.; Wertheim, H.F.L.; Sumpradit, N.; Vlieghe, E.; Hara, G.L.; Gould, I.M.; Goossens, H.; et al. Antibiotic resistance-The need for global solutions. Lancet Infect. Dis. 2013, 13, 1057-1098. [CrossRef]

77. Viertel, T.M.; Ritter, K.; Horz, H.-P. Viruses versus bacteria-Novel approaches to phage therapy as a tool against multidrugresistant pathogens. J. Antimicrob. Chemother. 2014, 69, 2326-2336. [CrossRef]

78. Skurnik, M.; Strauch, E. Phage therapy: Facts and fiction. Int. J. Med. Microbiol. 2006, 296, 5-14. [CrossRef]

79. Jassim, S.A.A.; Limoges, R.G. Natural Solution to Antibiotic Resistance: Bacteriophages 'the Living Drugs'. World J. Microbiol. Biotechnol. 2014, 30, 2153-2170. [CrossRef]

80. Abisado, R.G.; Benomar, S.; Klaus, J.R.; Dandekar, A.A.; Chandler, J.R.; Erratum for Abisado. “Bacterial Quorum Sensing and Microbial Community Interactions". mBio 2018, 9, e02331-17. [CrossRef]

81. Kramer, J.; Özkaya, Ö.; Kümmerli, R. Bacterial Siderophores in Community and Host Interactions. Nat. Rev. Microbiol. 2020, 18, 152-163. [CrossRef]

82. Visca, P.; Imperi, F.; Lamont, I.L. Pyoverdine siderophores: From biogenesis to biosignificance. Trends Microbiol. 2007, 15, 22-30. [CrossRef]

83. Guan, L.L.; Kanoh, K.; Kamino, K. Effect of Exogenous Siderophores on Iron Uptake Activity of Marine Bacteria under IronLimited Conditions. Appl. Environ. Microbiol. 2001, 67, 1710-1717. [CrossRef] [PubMed]

84. Li, Y.-H.; Tian, X. Quorum Sensing and Bacterial Social Interactions in Biofilms. Sensors 2012, 12, 2519-2538. [CrossRef]

85. Turovskiy, Y.; Chikindas, M.L. Autoinducer-2 bioassay is a qualitative, not quantitative method influenced by glucose. J. Microbiol. Methods 2006, 66, 497-503. [CrossRef] [PubMed]

86. Flemming, H.-C.; Wingender, H.-C.F.J.; Szewzyk, U.; Steinberg, P.; Rice, S.A.; Kjelleberg, S.A.R.S. Biofilms: An emergent form of bacterial life. Nat. Rev. Microbiol. 2016, 14, 563-575. [CrossRef] [PubMed]

87. Donlan, R.M.; Costerton, J.W. Biofilms: Survival Mechanisms of Clinically Relevant Microorganisms. Clin. Microbiol. Rev. 2002, 15, 167-193. [CrossRef]

88. Tolker-Nielsen, T. Biofilm Development. Microbiol. Spectr. 2015, 3. [CrossRef] [PubMed]

89. Jackson, D.W.; Suzuki, K.; Oakford, L.; Simecka, J.W.; Hart, M.E.; Romeo, T. Biofilm Formation and Dispersal under the Influence of the Global Regulator CsrA of Escherichia coli. J. Bacteriol. 2002, 184, 290-301. [CrossRef] [PubMed]

90. Li, Y.-H.; Tian, X.-L. Microbial Interactions in Biofilms: Impacts on Homeostasis and Pathogenesis; IntechOpen: London, UK, 2016.

91. Muhammad, M.H.; Idris, A.L.; Fan, X.; Guo, Y.; Yu, Y.; Jin, X.; Qiu, J.; Guan, X.; Huang, T. Beyond Risk: Bacterial Biofilms and Their Regulating Approaches. Front. Microbiol. 2020, 11, 928. [CrossRef]

92. Maksimova, Y. Microbial Biofilms in Biotechnological Processes. Appl. Biochem. Microbiol. 2014, 50, 750-760. [CrossRef]

93. Berlanga, M.; Guerrero, R. Living together in biofilms: The microbial cell factory and its biotechnological implications. Microb. Cell Factories 2016, 15, 1-11. [CrossRef]

94. Singh, S.; Singh, S.K.; Chowdhury, I.; Singh, R. Understanding the Mechanism of Bacterial Biofilms Resistance to Antimicrobial Agents. Open Microbiol. J. 2017, 11, 53-62. [CrossRef] [PubMed]

95. Nadell, C.D.; Drescher, C.D.N.K.; Foster, K.R. Spatial structure, cooperation and competition in biofilms. Nat. Rev. Genet. 2016, 14, 589-600. [CrossRef]

96. Stewart, P.S.; Franklin, M.J. Physiological heterogeneity in biofilms. Nat. Rev. Genet. 2008, 6, 199-210. [CrossRef]

97. Chang, Y.-W.; Fragkopoulos, A.A.; Marquez, S.M.; Kim, H.D.; Angelini, T.E.; Fernandez-Nieves, A. Biofilm formation in geometries with different surface curvature and oxygen availability. N. J. Phys. 2015, 17, 033017. [CrossRef]

98. Stal, L.J.; Bolhuis, H.; Cretoiu, M.S. Phototrophic marine benthic microbiomes: The ecophysiology of these biological entities. Environ. Microbiol. 2019, 21, 1529-1551. [CrossRef]

99. Dufrêne, Y.F.; Persat, A. Mechanomicrobiology: How bacteria sense and respond to forces. Nat. Rev. Genet. 2020, 18, 227-240. [CrossRef]

100. Rendueles, O.; Ghigo, J.-M. Mechanisms of Competition in Biofilm Communities. Microbiol. Spectr. 2015, 3. [CrossRef] [PubMed]

101. Roy, R.; Tiwari, M.; Donelli, G.; Tiwari, V. Strategies for combating bacterial biofilms: A focus on anti-biofilm agents and their mechanisms of action. Virulence 2018, 9, 522-554. [CrossRef]

102. Fuqua, W.C.; Winans, S.C.; Greenberg, E.P. Quorum Sensing in Bacteria: The Luxr-Luxi Family of Cell Density-Responsive Transcriptional Regulators. J. Bacteriol. 1994, 176, 269-275. [CrossRef] [PubMed]

103. Bassler, B.L. Small Talk. Cell-to-Cell Communication in Bacteria. Cell 2002, 109, 421-424. [CrossRef]

104. Castillo, A. How Bacteria Use Quorum Sensing to Communicate: How Do Bacteria Talk to Each Other. Nat. Educ. 2015, 8, 4. 
105. Landini, P.; Antoniani, D.; Burgess, J.G.; Nijland, R. Molecular mechanisms of compounds affecting bacterial biofilm formation and dispersal. Appl. Microbiol. Biotechnol. 2010, 86, 813-823. [CrossRef] [PubMed]

106. Castillo-Juárez, I.; Maeda, T.; Mandujano-Tinoco, E.A.; Tomás, M.; Rez-Eretza, S.J.G.; García-Contreras, S.J.; Wood, T.K.; García-Contreras, R. Role of quorum sensing in bacterial infections. World J. Clin. Cases 2015, 3, 575-598. [CrossRef] [PubMed]

107. Pacheco, A.R.; Sperandio, V. Inter-kingdom signaling: Chemical language between bacteria and host. Curr. Opin. Microbiol. 2009, 12, 192-198. [CrossRef]

108. Nealson, K.H.; Hastings, J.W. Bacterial Bioluminescence: Its Control and Ecological Significance. Microbiol. Rev. 1979, 43, 496-518. [CrossRef]

109. Rutherford, S.T.; Bassler, B.L. Bacterial Quorum Sensing: Its Role in Virulence and Possibilities for Its Control. Cold Spring Harb. Perspect. Med. 2012, 2, a012427. [CrossRef]

110. Lee, J.; Zhang, L. The hierarchy quorum sensing network in Pseudomonas aeruginosa. Protein Cell 2015, 6, 26-41. [CrossRef]

111. Truong, T.; Seyedsayamdost, M.; Greenberg, E.; Chandler, J.R. A Burkholderia thailandensis Acyl-Homoserine LactoneIndependent Orphan LuxR Homolog That Activates Production of the Cytotoxin Malleilactone. J. Bacteriol. 2015, 197, 3456-3462. [CrossRef] [PubMed]

112. Cornforth, D.M.; Popat, R.; McNally, L.; Gurney, J.; Scott-Phillips, T.C.; Ivens, A.; Diggle, S.P.; Brown, S.P. Combinatorial quorum sensing allows bacteria to resolve their social and physical environment. Proc. Natl. Acad. Sci. USA 2014, 111, 4280-4284. [CrossRef]

113. Verbeke, F.; De Craemer, S.; Debunne, N.; Janssens, Y.; Wynendaele, E.; Van De Wiele, C.; De Spiegeleer, B. Peptides as Quorum Sensing Molecules: Measurement Techniques and Obtained Levels In vitro and In vivo. Front. Neurosci. 2017, 11, 183. [CrossRef] [PubMed]

114. Novick, R.P.; Geisinger, E. Quorum Sensing in Staphylococci. Annu. Rev. Genet. 2008, 42, 541-564. [CrossRef]

115. Ng, W.-L.; Bassler, B.L. Bacterial Quorum-Sensing Network Architectures. Annu. Rev. Genet. 2009, 43, 197-222. [CrossRef] [PubMed]

116. Pereira, C.S.; Thompson, J.A.; Xavier, K.B. AI-2-mediated signalling in bacteria. FEMS Microbiol. Rev. 2013, 37, 156-181. [CrossRef]

117. Schauder, S.; Shokat, K.; Surette, M.G.; Bassler, B.L. The LuxS family of bacterial autoinducers: Biosynthesis of a novel quorumsensing signal molecule. Mol. Microbiol. 2001, 41, 463-476. [CrossRef] [PubMed]

118. Winzer, K.; Hardie, K.R.; Burgess, N.; Doherty, N.; Kirke, D.; Holden, M.; Linforth, R.; Cornell, K.A.; Taylor, A.J.; Hill, P.J.; et al. LuxS: Its role in central metabolism and the in vitro synthesis of 4-hydroxy-5-methyl-3(2H)-furanone. Microbiology 2002, 148, 909-922. [CrossRef] [PubMed]

119. Chen, X.; Schauder, S.; Potier, N.; Van Dorsselaer, A.; Pelczer, I.; Bassler, B.L.; Hughson, F.M. Structural identification of a bacterial quorum-sensing signal containing boron. Nat. Cell Biol. 2002, 415, 545-549. [CrossRef] [PubMed]

120. Miller, S.T.; Xavier, K.B.; Campagna, S.R.; Taga, M.E.; Semmelhack, M.F.; Bassler, B.L.; Hughson, F.M. Salmonella typhimurium Recognizes a Chemically Distinct Form of the Bacterial Quorum-Sensing Signal AI-2. Mol. Cell 2004, 15, 677-687. [CrossRef] [PubMed]

121. Rui, F.; Marques, J.C.; Miller, S.T.; Maycock, C.D.; Xavier, K.B.; Ventura, M.R. Stereochemical diversity of AI-2 analogs modulates quorum sensing in Vibrio harveyi and Escherichia coli. Bioorg. Med. Chem. 2012, 20, 249-256. [CrossRef]

122. Frederix, M.; Downie, J.A. Chapter 2-Quorum Sensing: Regulating the Regulators. In Advances in Microbial Physiology; Poole, R.K., Ed.; Academic Press: Cambridge, MA, USA, 2011; pp. 23-80.

123. Ng, W.; Perez, L.J.; Wei, Y.; Kraml, C.; Semmelhack, M.F.; Bassler, B.L. Signal production and detection specificity in Vibrio CqsA/CqsS quorum-sensing systems. Mol. Microbiol. 2011, 79, 1407-1417. [CrossRef]

124. Bassler, B.L.; Miller, M.B. Quorum Sensing. In The Prokaryotes; Springer: Berlin/Heidelberg, Germany, 2013 ; pp. $495-509$.

125. West, S.A.; Griffin, A.S.; Gardner, A.; Diggle, S.P. Social evolution theory for microorganisms. Nat. Rev. Genet. 2006, 4, 597-607. [CrossRef]

126. Diggle, S.P.; Griffin, A.S.; Campbell, G.S.; West, S. Cooperation and conflict in quorum-sensing bacterial populations. Nat. Cell Biol. 2007, 450, 411-414. [CrossRef]

127. Sandoz, K.M.; Mitzimberg, S.M.; Schuster, M. Social cheating in Pseudomonas aeruginosa quorum sensing. Proc. Natl. Acad. Sci. USA 2007, 104, 15876-15881. [CrossRef]

128. Venturi, V.; Bertani, I.; Kerényi, Á.; Netotea, S.; Pongor, S. Co-Swarming and Local Collapse: Quorum Sensing Conveys Resilience to Bacterial Communities by Localizing Cheater Mutants in Pseudomonas Aeruginosa. PLoS ONE 2010, 5, e9998. [CrossRef]

129. Xavier, J.B.; Kim, W.; Foster, K.R. A molecular mechanism that stabilizes cooperative secretions in Pseudomonas aeruginosa. Mol. Microbiol. 2010, 79, 166-179. [CrossRef]

130. Oslizlo, A.; Stefanic, P.; Dogsa, I.; Mandic-Mulec, I. Private link between signal and response in Bacillus subtilis quorum sensing. Proc. Natl. Acad. Sci. USA 2014, 111, 1586-1591. [CrossRef]

131. van der Ploeg, J.R. Regulation of Bacteriocin Production in Streptococcus Mutans by the Quorum-Sensing System Required for Development of Genetic Competence. J. Bacteriol. 2005, 187, 3980-3989. [CrossRef]

132. Fontaine, L.; Boutry, C.; Guédon, E.; Guillot, A.; Ibrahim, M.; Grossiord, B.; Hols, P. Quorum-Sensing Regulation of the Production of Blp Bacteriocins in Streptococcus Thermophilus. J. Bacteriol. 2007, 189, 7195-7205. [CrossRef]

133. Majerczyk, C.; Schneider, E.; Greenberg, E.P. Quorum sensing control of Type VI secretion factors restricts the proliferation of quorum-sensing mutants. eLife 2016, 5, 317. [CrossRef] [PubMed] 
134. Mazzola, M.; Cook, R.J.; Thomashow, L.S.; Weller, D.M.; Pierson, L.S. Contribution of Phenazine Antibiotic Biosynthesis to the Ecological Competence of Fluorescent Pseudomonads in Soil Habitats. Appl. Environ. Microbiol. 1992, 58, 2616-2624. [CrossRef] [PubMed]

135. Smalley, N.E.; An, D.; Parsek, M.R.; Chandler, J.R.; Dandekar, A.A. Quorum Sensing Protects Pseudomonas aeruginosa against Cheating by Other Species in a Laboratory Coculture Model. J. Bacteriol. 2015, 197, 3154-3159. [CrossRef] [PubMed]

136. Telford, G.; Wheeler, D.; Williams, P.; Tomkins, P.T.; Appleby, P.; Sewell, H.; Stewart, G.S.A.B.; Bycroft, B.W.; Pritchard, D.I. The Pseudomonas aeruginosaQuorum-Sensing Signal MoleculeN-(3-Oxododecanoyl)-1-Homoserine Lactone Has Immunomodulatory Activity. Infect. Immun. 1998, 66, 36-42. [CrossRef] [PubMed]

137. Sperandio, V.; Torres, A.G.; Jarvis, B.; Nataro, J.P.; Kaper, J.B. Bacteria-host communication: The language of hormones. Proc. Natl. Acad. Sci. USA 2003, 100, 8951-8956. [CrossRef]

138. King, N. The Unicellular Ancestry of Animal Development. Dev. Cell 2004, 7, 313-325. [CrossRef] [PubMed]

139. Joint, I.; Tait, K.; Callow, M.E.; Callow, J.A.; Milton, D.; Williams, P.; Cámara, M. Cell-to-Cell Communication Across the Prokaryote-Eukaryote Boundary. Science 2002, 298, 1207. [CrossRef]

140. Singh, R.P.; Reddy, C. Seaweed-microbial interactions: Key functions of seaweed-associated bacteria. FEMS Microbiol. Ecol. 2014, 88, 213-230. [CrossRef]

141. Joseph, C.M.; Phillips, D.A. Metabolites from soil bacteria affect plant water relations. Plant. Physiol. Biochem. 2003, 41, 189-192. [CrossRef]

142. Mathesius, U.; Mulders, S.; Gao, M.; Teplitski, M.; Caetano-Anolles, G.; Rolfe, B.G.; Bauer, W.D. Extensive and specific responses of a eukaryote to bacterial quorum-sensing signals. Proc. Natl. Acad. Sci. USA 2003, 100, 1444-1449. [CrossRef]

143. Gao, M.; Teplitski, M.; Robinson, J.B.; Bauer, W.D. Production of Substances by Medicago truncatula that Affect Bacterial Quorum Sensing. Mol. Plant. Microbe Interact. 2003, 16, 827-834. [CrossRef]

144. Givskov, M.; De Nys, R.; Manefield, M.; Gram, L.; Maximilien, R.; Eberl, L.; Molin, S.; Steinberg, P.D.; Kjelleberg, S. Eukaryotic interference with homoserine lactone-mediated prokaryotic signalling. J. Bacteriol. 1996, 178, 6618-6622. [CrossRef]

145. de Nys, R.; Givskov, M.; Kumar, N.; Kjelleberg, S.; Steinberg, P.D. Furanones. Prog Mol. Subcell. Biol. 2006, 42, 55-86. [PubMed]

146. Wu, H.; Song, Z.; Hentzer, M.; Andersen, J.B.; Molin, S.; Givskov, M.; Høiby, N. Synthetic furanones inhibit quorum-sensing and enhance bacterial clearance in Pseudomonas aeruginosa lung infection in mice. J. Antimicrob. Chemother. 2004, 53, $1054-1061$. [CrossRef] [PubMed]

147. Sanchez-Contreras, M.; Bauer, W.D.; Gao, M.; Robinson, J.B.; Downie, J.A. Quorum-sensing regulation in rhizobia and its role in symbiotic interactions with legumes. Philos. Trans. R. Soc. B Biol. Sci. 2007, 362, 1149-1163. [CrossRef] [PubMed]

148. Bauer, W.D.; Mathesius, U. Plant responses to bacterial quorum sensing signals. Curr. Opin. Plant. Biol. 2004, 7, 429-433. [CrossRef]

149. Albuquerque, P.; Arturo, C. Quorum Sensing in Fungi-A Review. Med. Mycol. 2012, 50, 337-345. [CrossRef]

150. De Sordi, L.; Mühlschlegel, F.A. Quorum Sensing and Fungal-Bacterial Interactions in Candida Albicans: A Communicative Network Regulating Microbial Coexistence and Virulence. FEMS Yeast Res. 2009, 9, 990-999. [CrossRef] [PubMed]

151. Hornby, J.M.; Jensen, E.C.; Lisec, A.D.; Tasto, J.J.; Jahnke, B.; Shoemaker, R.; Dussault, P.H.; Nickerson, K.W. Quorum Sensing in the Dimorphic FungusCandida albicans Is Mediated by Farnesol. Appl. Environ. Microbiol. 2001, 67, 2982-2992. [CrossRef] [PubMed]

152. Hogan, D.A. Talking to Themselves: Autoregulation and Quorum Sensing in Fungi. Eukaryot. Cell 2006, 5, 613-619. [CrossRef]

153. Lee, H.; Chang, Y.C.; Nardone, G.; Kwon-Chung, K.J. TUP1 disruption in Cryptococcus neoformans uncovers a peptide-mediated density-dependent growth phenomenon that mimics quorum sensing. Mol. Microbiol. 2007, 64, 591-601. [CrossRef] [PubMed]

154. Affeldt, K.J.; Brodhagen, M.; Keller, N.P. Aspergillus Oxylipin Signaling and Quorum Sensing Pathways Depend on G ProteinCoupled Receptors. Toxins 2012, 4, 695-717. [CrossRef]

155. Chen, H.; Fujita, M.; Feng, Q.; Clardy, J.; Fink, G.R. Tyrosol is a quorum-sensing molecule in Candida albicans. Proc. Natl. Acad. Sci. USA 2004, 101, 5048-5052. [CrossRef]

156. Nakano, M.; Takahashi, A.; Sakai, Y.; Nakaya, Y. Modulation of Pathogenicity with Norepinephrine Related to the Type III Secretion System ofVibrio parahaemolyticus. J. Infect. Dis. 2007, 195, 1353-1360. [CrossRef]

157. Clarke, M.B.; Hughes, D.T.; Zhu, C.; Boedeker, E.C.; Sperandio, V. The QseC sensor kinase: A bacterial adrenergic receptor. Proc. Natl. Acad. Sci. USA 2006, 103, 10420-10425. [CrossRef]

158. Zaborina, O.; Lepine, F.; Xiao, G.; Valuckaite, V.; Chen, Y.; Li, T.; Ciancio, M.; Zaborin, A.; Petroff, E.; Turner, J.R. Dynorphin Activates Quorum Sensing Quinolone Signaling in Pseudomonas Aeruginosa. PLoS Pathog. 2007, 3, e35.

159. Kravchenko, V.V.; Kaufmann, G.F.; Mathison, J.C.; Scott, D.A.; Katz, A.Z.; Grauer, D.C.; Lehmann, M.; Meijler, M.M.; Janda, K.D.; Ulevitch, R.J. Modulation of Gene Expression Via Disruption of Nf-Kappab Signaling by a Bacterial Small Molecule. Science 2008, 321, 259-263. [CrossRef] [PubMed]

160. Shiner, E.K.; Terentyev, D.; Bryan, A.; Sennoune, S.; Martinez-Zaguilan, R.; Li, G.; Gyorke, S.; Williams, S.C.; Rumbaugh, K.P. Pseudomonas aeruginosa autoinducer modulates host cell responses through calcium signalling. Cell. Microbiol. 2006, 8, 1601-1610. [CrossRef] [PubMed]

161. Fujiya, M.; Musch, M.W.; Nakagawa, Y.; Hu, S.; Alverdy, J.; Kohgo, Y.; Schneewind, O.; Jabri, B.; Chang, E.B. The Bacillus subtilis Quorum-Sensing Molecule CSF Contributes to Intestinal Homeostasis via OCTN2, a Host Cell Membrane Transporter. Cell Host Microbe 2007, 1, 299-308. [CrossRef] [PubMed] 
162. Lenz, D.H.; Mok, K.C.; Lilley, B.N.; Kulkarni, R.V.; Wingreen, N.S.; Bassler, B.L. The Small RNA Chaperone Hfq and Multiple Small RNAs Control Quorum Sensing in Vibrio harveyi and Vibrio cholerae. Cell 2004, 118, 69-82. [CrossRef]

163. Waters, C.M.; Bassler, B.L. Quorum Sensing: Cell-to-Cell Communication in Bacteria. Annu. Rev. Cell Dev. Biol. 2005, 21, 319-346. [CrossRef]

164. Ni, N.; Li, M.; Wang, J.; Wang, B. Inhibitors and antagonists of bacterial quorum sensing. Med. Res. Rev. 2008, 29, 65-124. [CrossRef]

165. LaSarre, B.; Federle, M.J. Exploiting Quorum Sensing To Confuse Bacterial Pathogens. Microbiol. Mol. Biol. Rev. $2013,77,73-111$. [CrossRef] [PubMed]

166. Grandclément, C.; Tannières, M.; Moréra, S.; Dessaux, Y.; Faure, D.D. Quorum quenching: Role in nature and applied developments. FEMS Microbiol. Rev. 2016, 40, 86-116. [CrossRef]

167. Webb, J.S.; Givskov, M.; Kjelleberg, S. Bacterial biofilms: Prokaryotic adventures in multicellularity. Curr. Opin. Microbiol. 2003, 6, 578-585. [CrossRef]

168. Reuter, K.; Steinbach, A.; Helms, V. Interfering with Bacterial Quorum Sensing. Perspect. Med. Chem. 2016, 8. [CrossRef]

169. Pomianek, M.E.; Semmelhack, M.F. Making Bacteria Behave: New Agonists and Antagonists of Quorum Sensing. ACS Chem. Biol. 2007, 2, 293-295. [CrossRef] [PubMed]

170. Wysoczynski-Horita, C.L.; Boursier, M.E.; Hill, R.; Hansen, K.; Blackwell, H.E.; Churchill, M.E.A. Mechanism of agonism and antagonism of the Pseudomonas aeruginosa quorum sensing regulator QscR with non-native ligands. Mol. Microbiol. 2018, 108, 240-257. [CrossRef]

171. Estephane, J.; Dauvergne, J.; Soulère, L.; Reverchon, S.; Queneau, Y.; Doutheau, A. N-Acyl-3-Amino-5h-Furanone Derivatives as New Inhibitors of Luxr-Dependent Quorum Sensing: Synthesis, Biological Evaluation and Binding Mode Study. Bioorg. Med. Chem. Lett. 2008, 18, 4321-4324. [CrossRef]

172. Holden, M.; Chhabra, S.R.; De Nys, R.; Stead, P.; Bainton, N.J.; Hill, P.J.; Manefield, M.; Kumar, N.; Labatte, M.; England, D.; et al. Quorum-sensing cross talk: Isolation and chemical characterization of cyclic dipeptides from Pseudomonas aeruginosa and other Gram-negative bacteria. Mol. Microbiol. 2002, 33, 1254-1266. [CrossRef] [PubMed]

173. Draganov, D.I.; Teiber, J.F.; Speelman, A.; Osawa, Y.; Sunahara, R.; La Du, B.N. Human paraoxonases (PON1, PON2, and PON3) are lactonases with overlapping and distinct substrate specificities. J. Lipid Res. 2005, 46, 1239-1247. [CrossRef] [PubMed]

174. Lyon, G.J.; Wright, J.S.; Christopoulos, A.; Novick, R.P.; Muir, T.W. Reversible and Specific Extracellular Antagonism of ReceptorHistidine Kinase Signaling. J. Biol. Chem. 2002, 277, 6247-6253. [CrossRef] [PubMed]

175. Lyon, G.J.; Wright, J.S.; Muir, T.W.; Novick, R.P. Key Determinants of Receptor Activation in the Agr Autoinducing Peptides of Staphylococcus Aureus. Biochemistry 2002, 41, 10095-10104. [CrossRef]

176. Alfaro, J.F.; Zhang, T.; Wynn, D.P.; Karschner, E.L.; Zhou, Z.S. Synthesis of LuxS Inhibitors Targeting Bacterial Cell-Cell Communication. Org. Lett. 2004, 6, 3043-3046. [CrossRef]

177. Yang, G.; Gao, Y.; Dong, J.; Xue, Y.; Fan, M.; Shen, B.; Liu, C.; Shao, N. A novel peptide isolated from phage library to substitute a complex system for a vaccine against staphylococci infection. Vaccine 2006, 24, 1117-1123. [CrossRef]

178. Singh, V.; Shi, W.; Almo, S.C.; Evans, G.B.; Furneaux, R.H.; Tyler, P.C.; Painter, G.F.; Lenz, D.H.; Mee, S.; Zheng, R.; et al. Structure and Inhibition of a Quorum Sensing Target fromStreptococcus pneumoniaet. Biochemistry 2006, 45, 12929-12941. [CrossRef]

179. Lowery, C.A.; Abe, T.; Park, J.; Eubanks, L.M.; Sawada, D.; Kaufmann, G.F.; Janda, K.D. Revisiting AI-2 Quorum Sensing Inhibitors: Direct Comparison of Alkyl-DPD Analogues and a Natural Product Fimbrolide. J. Am. Chem. Soc. 2009, 131, 15584-15585. [CrossRef] [PubMed]

180. Semmelhack, M.F.; Campagna, S.R.; Hwa, C.; Federle, M.J.; Bassler, B.L. Boron Binding with the Quorum Sensing Signal AI-2 and Analogues. Org. Lett. 2004, 6, 2635-2637. [CrossRef] [PubMed]

181. Ren, D.; Sims, J.J.; Wood, T.K. Inhibition of biofilm formation and swarming of Escherichia coli by (5Z)-4-bromo-5(bromomethylene)-3-butyl-2(5H)-furanone. Environ. Microbiol. 2001, 3, 731-736. [CrossRef]

182. Ren, D.; Zuo, R.; Wood, T.K. Quorum-sensing antagonist (5Z)-4-bromo-5-(bromomethylene)-3-butyl-2(5H)-furanone influences siderophore biosynthesis in Pseudomonas putida and Pseudomonas aeruginosa. Appl. Microbiol. Biotechnol. 2004, 66, 689-695. [CrossRef] [PubMed]

183. Lee, J.; Jayaraman, A.; Wood, T.K. Indole is an inter-species biofilm signal mediated by SdiA. BMC Microbiol. 2007, 7, 42. [CrossRef]

184. Bassler, B.L.; Wright, M.; Showalter, R.E.; Silverman, M.R. Intercellular signalling in Vibrio harveyi: Sequence and function of genes regulating expression of luminescence. Mol. Microbiol. 1993, 9, 773-786. [CrossRef]

185. Widmer, K.; Soni, K.A.; Hume, M.; Beier, R.; Jesudhasan, P.; Pillai, S. Identification of Poultry Meat-Derived Fatty Acids Functioning as Quorum Sensing Signal Inhibitors to Autoinducer-2 (AI-2). J. Food Sci. 2007, 72, M363-M368. [CrossRef]

186. Paluch, E.; Rewak-Soroczyńska, J.; Jędrusik, I.; Mazurkiewicz, E.; Jermakow, K. Prevention of biofilm formation by quorum quenching. Appl. Microbiol. Biotechnol. 2020, 104, 1871-1881. [CrossRef]

187. Yates, E.A.; Philipp, B.; Buckley, C.; Atkinson, S.; Chhabra, S.R.; Sockett, R.E.; Goldner, M.; Dessaux, Y.; Cámara, M.; Smith, H.; et al. N-Acylhomoserine Lactones Undergo Lactonolysis in a pH-, Temperature-, and Acyl Chain Length-Dependent Manner during Growth of Yersinia pseudotuberculosis and Pseudomonas aeruginosa. Infect. Immun. 2002, 70, 5635-5646. [CrossRef]

188. Leadbetter, J.R.; Greenberg, E. Metabolism of Acyl-Homoserine Lactone Quorum-Sensing Signals by Variovorax paradoxus. J. Bacteriol. 2000, 182, 6921-6926. [CrossRef] 
189. Huang, J.J.; Han, J.-I.; Zhang, L.-H.; Leadbetter, J.R. Utilization of Acyl-Homoserine Lactone Quorum Signals for Growth by a Soil Pseudomonad and Pseudomonas aeruginosa PAO1. Appl. Environ. Microbiol. 2003, 69, 5941-5949. [CrossRef] [PubMed]

190. Dong, Y.H.; Xu, J.L.; Li, X.Z.; Zhang, L.H. Aiia, an Enzyme That Inactivates the Acylhomoserine Lactone Quorum-Sensing Signal and Attenuates the Virulence of Erwinia Carotovora. Proc. Natl. Acad. Sci. USA 2000, 97, 3526-3531. [CrossRef] [PubMed]

191. Dong, Y.-H.; Wang, L.-H.; Xu, J.-L.; Zhang, H.-B.; Zhang, X.-F.; Zhang, L.-H. Quenching quorum-sensing-dependent bacterial infection by an N-acyl homoserine lactonase. Nat. Cell Biol. 2001, 411, 813-817. [CrossRef]

192. Dong, Y.-H.; Gusti, A.; Zhang, Q.; Xu, J.-L.; Zhang, L.-H. Identification of Quorum-Quenching N-Acyl Homoserine Lactonases from Bacillus Species. Appl. Environ. Microbiol. 2002, 68, 1754-1759. [CrossRef] [PubMed]

193. Park, S.-Y.; Lee, S.J.; Oh, T.-K.; Oh, J.-W.; Koo, B.-T.; Yum, D.-Y.; Lee, J.-K. AhlD, an N-acylhomoserine lactonase in Arthrobacter sp., and predicted homologues in other bacteria. Microbiology 2003, 149, 1541-1550. [CrossRef]

194. Carlier, A.; Uroz, S.; Smadja, B.; Fray, R.; Latour, X.; Dessaux, Y.; Faure, D. The Ti Plasmid of Agrobacterium Tumefaciens Harbors an Attm-Paralogous Gene, Aiib, also Encoding N-Acyl Homoserine Lactonase Activity. Appl. Environ. Microbiol. 2003, 69, 4989-4993. [CrossRef] [PubMed]

195. Wang, L.-H.; Weng, L.-X.; Dong, Y.-H.; Zhang, L.-H. Specificity and Enzyme Kinetics of the Quorum-quenching N-Acyl Homoserine Lactone Lactonase (AHL-lactonase). J. Biol. Chem. 2004, 279, 13645-13651. [CrossRef] [PubMed]

196. Ozer, E.A.; Pezzulo, A.; Shih, D.M.; Chun, C.; Furlong, C.; Lusis, A.J.; Greenberg, E.; Zabner, J. Human and murine paraoxonase 1 are host modulators of Pseudomonas aeruginosa quorum-sensing. FEMS Microbiol. Lett. 2005, 253, 29-37. [CrossRef]

197. Chun, C.K.; Ozer, E.A.; Welsh, M.; Zabner, J.; Greenberg, E.P. From The Cover: Inactivation of a Pseudomonas aeruginosa quorum-sensing signal by human airway epithelia. Proc. Natl. Acad. Sci. USA 2004, 101, 3587-3590. [CrossRef] [PubMed]

198. Yang, F.; Wang, L.-H.; Wang, J.; Dong, Y.-H.; Hu, J.Y.; Zhang, L.-H. Quorum quenching enzyme activity is widely conserved in the sera of mammalian species. FEBS Lett. 2005, 579, 3713-3717. [CrossRef]

199. Billecke, S.; Draganov, D.; Counsell, R.; Stetson, P.; Watson, C.; Hsu, C.; La Du, B.N. Human serum paraoxonase (PON1) isozymes $\mathrm{Q}$ and $\mathrm{R}$ hydrolyze lactones and cyclic carbonate esters. Drug Metab. Dispos. 2000, 28, 1335-1342. [PubMed]

200. Hu, J.Y.; Fan, Y.; Lin, Y.-H.; Zhang, H.-B.; Ong, S.L.; Dong, N.; Xu, J.-L.; Ng, W.J.; Zhang, L.-H. Microbial diversity and prevalence of virulent pathogens in biofilms developed in a water reclamation system. Res. Microbiol. 2003, 154, 623-629. [CrossRef]

201. Huang, S.; Hadfield, M. Composition and density of bacterial biofilms determine larval settlement of the polychaete Hydroides elegans. Mar. Ecol. Prog. Ser. 2003, 260, 161-172. [CrossRef]

202. Lin, Y.-H.; Xu, J.-L.; Hu, J.; Wang, L.-H.; Ong, S.L.; Leadbetter, J.R.; Zhang, L.-H. Acyl-homoserine lactone acylase from Ralstonia strain XJ12B represents a novel and potent class of quorum-quenching enzymes. Mol. Microbiol. 2003, 47, 849-860. [CrossRef]

203. Uroz, S.; Chhabra, S.R.; Cámara, M.; Williams, P.; Oger, P.; Dessaux, Y. N-Acylhomoserine lactone quorum-sensing molecules are modified and degraded by Rhodococcus erythropolis W2 by both amidolytic and novel oxidoreductase activities. Microbiology 2005, 151, 3313-3322. [CrossRef] [PubMed]

204. Zhu, J.; Beaber, J.W.; More, M.I.; Fuqua, C.; Eberhard, A.; Winans, S.C. Analogs of the Autoinducer 3-Oxooctanoyl-Homoserine Lactone Strongly Inhibit Activity of the Trar Protein of Agrobacterium Tumefaciens. J. Bacteriol. 1998, 180, 5398-5405. [CrossRef]

205. Sheppard, F.R.; Kelher, M.R.; Moore, E.E.; McLaughlin, N.J.D.; Banerjee, A.; Silliman, C.C. Structural organization of the neutrophil NADPH oxidase: Phosphorylation and translocation during priming and activation. J. Leukoc. Biol. 2005, 78, 1025-1042. [CrossRef]

206. Rothfork, J.M.; Timmins, G.; Harris, M.N.; Chen, X.; Lusis, A.J.; Otto, M.; Cheung, A.L.; Gresham, H.D. Inactivation of a bacterial virulence pheromone by phagocyte-derived oxidants: New role for the NADPH oxidase in host defense. Proc. Natl. Acad. Sci. USA 2004, 101, 13867-13872. [CrossRef]

207. McDowell, J.W.; Paulson, D.S.; Mitchell, J.A. A simulated-use evaluation of a strategy for preventing biofilm formation in dental unit waterlines. J. Am. Dent. Assoc. 2004, 135, 799-805. [CrossRef]

208. Roy, V.; Fernandes, R.; Tsao, C.-Y.; Bentley, W.E. Cross Species Quorum Quenching Using a Native AI-2 Processing Enzyme. ACS Chem. Biol. 2010, 5, 223-232. [CrossRef]

209. Weiland-Bräuer, N.; Kisch, M.J.; Pinnow, N.; Liese, A.; Schmitz-Streit, R.A. Highly Effective Inhibition of Biofilm Formation by the First Metagenome-Derived AI-2 Quenching Enzyme. Front. Microbiol. 2016, 7, 1098. [CrossRef]

210. Haudecoeur, E.; Faure, D. A fine control of quorum-sensing communication in Agrobacterium tumefaciens. Commun. Integr. Biol. 2010, 3, 84-88. [CrossRef] [PubMed]

211. Utari, P.D.; Vogel, J.; Quax, W.J. Deciphering Physiological Functions of AHL Quorum Quenching Acylases. Front. Microbiol. 2017, 8, 1123. [CrossRef] [PubMed]

212. Xavier, K.B.; Bassler, B.L. Regulation of Uptake and Processing of the Quorum-Sensing Autoinducer AI-2 in Escherichia coli. J. Bacteriol. 2005, 187, 238-248. [CrossRef]

213. Hong, K.W.; Koh, C.L.; Sam, C.-K.; Yin, W.-F.; Chan, K.-G. Quorum Quenching Revisited—From Signal Decays to Signalling Confusion. Sensors 2012, 12, 4661-4696. [CrossRef] [PubMed]

214. Park, S.-J.; Park, S.-Y.; Ryu, C.-M.; Park, S.-H.; Lee, J.-K. The role of AiiA, a quorum-quenching enzyme from Bacillus thuringiensis, on the rhizosphere competence. J. Microbiol. Biotechnol. 2008, 18, 1518-1521. [PubMed]

215. Mochizuki, H.; Scherer, S.W.; Xi, T.; Nickle, D.C.; Majer, M.; Huizenga, J.J.; Tsui, L.-C.; Prochazka, M. Human PON2 gene at 7q21.3: Cloning, multiple mRNA forms, and missense polymorphisms in the coding sequence. Gene 1998, 213, 149-157. [CrossRef] 
216. Stoltz, D.A.; Ozer, E.A.; Ng, C.J.; Yu, J.M.; Reddy, S.T.; Lusis, A.J.; Bourquard, N.; Parsek, M.R.; Zabner, J.; Shih, D.M. Paraoxonase2 Deficiency Enhances Pseudomonas Aeruginosa Quorum Sensing in Murine Tracheal Epithelia. Am. J. Physiol. Lung Cell. Mol. Physiol. 2007, 292, L852-L860. [CrossRef]

217. Teasdale, M.E.; Liu, J.; Wallace, J.; Akhlaghi, F.; Rowley, D.C. Secondary Metabolites Produced by the Marine Bacterium Halobacillus salinus That Inhibit Quorum Sensing-Controlled Phenotypes in Gram-Negative Bacteria. Appl. Environ. Microbiol. 2008, 75, 567-572. [CrossRef]

218. Dong, Y.-H.; Zhang, L.-H. Quorum sensing and quorum-quenching enzymes. J. Microbiol. 2005, 43, 101-109.

219. Kiran, G.S.; Hassan, S.; Sajayan, A.; Selvin, J. Quorum Quenching Compounds from Natural Sources. In Bioresources and Bioprocess in Biotechnology; Springer Science and Business Media LLC.: Berlin/Heidelberg, Germany, 2017; pp. 351-364.

220. Fetzner, S. Quorum quenching enzymes. J. Biotechnol. 2015, 201, 2-14. [CrossRef] [PubMed]

221. Jiang, Q.; Chen, J.; Yang, C.; Yin, Y.; Yao, K. Quorum Sensing: A Prospective Therapeutic Target for Bacterial Diseases. BioMed Res. Int. 2019, 2019, 1-15. [CrossRef]

222. Bhardwaj, A.K.; Vinothkumar, K.; Rajpara, N. Bacterial Quorum Sensing Inhibitors: Attractive Alternatives for Control of Infectious Pathogens Showing Multiple Drug Resistance. Recent Pat. Anti-Infect. Drug Discov. 2013, 8, 68-83. [CrossRef]

223. Koo, H.; Allan, R.N.; Howlin, R.P.; Stoodley, P.; Hall-Stoodley, L. Targeting microbial biofilms: Current and prospective therapeutic strategies. Nat. Rev. Genet. 2017, 15, 740-755. [CrossRef]

224. Rémy, B.; Mion, S.; Plener, L.; Elias, M.; Chabrière, E.; Daudé, D. Interference in Bacterial Quorum Sensing: A Biopharmaceutical Perspective. Front. Pharmacol. 2018, 9, 203. [CrossRef]

225. Defoirdt, T.; Sorgeloos, P.; Bossier, P. Alternatives to antibiotics for the control of bacterial disease in aquaculture. Curr. Opin. Microbiol. 2011, 14, 251-258. [CrossRef]

226. Natrah, F.M.I.; Defoirdt, T.; Sorgeloos, P.; Bossier, P. Disruption of Bacterial Cell-to-Cell Communication by Marine Organisms and its Relevance to Aquaculture. Mar. Biotechnol. 2011, 13, 109-126. [CrossRef] [PubMed]

227. Tinh, N.; Linh, N.; Wood, T.; Dierckens, K.; Sorgeloos, P.; Bossier, P. Interference with the quorum sensing systems in a Vibrio harveyi strain alters the growth rate of gnotobiotically cultured rotifer Brachionus plicatilis. J. Appl. Microbiol. 2006, 103, 194-203. [CrossRef]

228. Tinh, N.T.N.; Yen, V.H.N.; Dierckens, K.; Sorgeloos, P.; Bossier, P. An acyl homoserine lactone-degrading microbial community improves the survival of first-feeding turbot larvae (Scophthalmus maximus L.). Aquaculture 2008, 285, 56-62. [CrossRef]

229. Rasch, M.; Buch, C.; Austin, B.; Slierendrecht, W.J.; Ekmann, K.S.; Larsen, J.L.; Johansen, C.; Riedel, K.; Eberl, L.; Givskov, M.; et al. An Inhibitor of Bacterial Quorum Sensing Reduces Mortalities Caused by Vibriosis in Rainbow Trout (Oncorhynchus mykiss, Walbaum). Syst. Appl. Microbiol. 2004, 27, 350-359. [CrossRef] [PubMed]

230. Defoirdt, T.; Crab, R.; Wood, T.K.; Sorgeloos, P.; Verstraete, W.; Bossier, P. Quorum Sensing-Disrupting Brominated Furanones Protect the Gnotobiotic Brine Shrimp Artemia franciscana from Pathogenic Vibrio harveyi, Vibrio campbellii, and Vibrio parahaemolyticus Isolates. Appl. Environ. Microbiol. 2006, 72, 6419-6423. [CrossRef] [PubMed]

231. Morohoshi, T.; Ebata, A.; Nakazawa, S.; Kato, N.; Ikeda, T. N-acyl Homoserine Lactone-Producing or -Degrading Bacteria Isolated from the Intestinal Microbial Flora of Ayu Fish (Plecoglossus altivelis). Microbes Environ. 2005, 20, 264-268. [CrossRef]

232. Morohoshi, T.; Nakazawa, S.; Ebata, A.; Kato, N.; Ikeda, T. Identification and Characterization of N-Acylhomoserine LactoneAcylase from the Fish Intestinal Shewanella Sp. Strain Mib015. Biosci. Biotechnol. Biochem. 2008, 72, 1887-1893. [CrossRef]

233. Van Cam, D.T.; Nhan, D.T.; Ceuppens, S.; Van Hao, N.; Dierckens, K.; Wille, M.; Sorgeloos, P.; Bossier, P. Effect of N-acyl homoserine lactone-degrading enrichment cultures on Macrobrachium rosenbergii larviculture. Aquaculture 2009, $294,5-13$. [CrossRef]

234. Dobretsov, S.; Teplitski, M.; Bayer, M.; Gunasekera, S.; Proksch, P.; Paul, V.J. Inhibition of marine biofouling by bacterial quorum sensing inhibitors. Biofouling 2011, 27, 893-905. [CrossRef] [PubMed]

235. Gül, B.Y.; Imer, D.Y.; Park, P.-K.; Koyuncu, I. Selection of quorum quenching (QQ) bacteria for membrane biofouling control: Effect of different Gram-staining QQ bacteria, Bacillus sp. T5 and Delftia sp. T6, on microbial population in membrane bioreactors. Water Sci. Technol. 2018, 78, 358-366. [CrossRef] [PubMed]

236. Swift, S.; Karlyshev, A.; Fish, L.; Durant, E.L.; Winson, M.K.; Chhabra, S.R.; Williams, P.; MacIntyre, S.; Stewart, G.S. Quorum sensing in Aeromonas hydrophila and Aeromonas salmonicida: Identification of the LuxRI homologs AhyRI and AsaRI and their cognate N-acylhomoserine lactone signal molecules. J. Bacteriol. 1997, 179, 5271-5281. [CrossRef] [PubMed]

237. Paul, D.; Kim, Y.S.; Ponnusamy, K.; Kweon, J.H. Application of Quorum Quenching to Inhibit Biofilm Formation. Environ. Eng. Sci. 2009, 26, 1319-1324. [CrossRef]

238. Kim, J.-H.; Choi, D.-C.; Yeon, K.-M.; Kim, S.-R.; Lee, C.-H. Enzyme-Immobilized Nanofiltration Membrane To Mitigate Biofouling Based on Quorum Quenching. Environ. Sci. Technol. 2011, 45, 1601-1607. [CrossRef]

239. Yeon, K.-M.; Lee, C.-H.; Kim, J. Magnetic Enzyme Carrier for Effective Biofouling Control in the Membrane Bioreactor Based on Enzymatic Quorum Quenching. Environ. Sci. Technol. 2009, 43, 7403-7409. [CrossRef]

240. Choudhary, S.; Schmidt-Dannert, C. Applications of quorum sensing in biotechnology. Appl. Microbiol. Biotechnol. 2010, 86, 1267-1279. [CrossRef]

241. Dulla, G.F.J.; Lindow, S.E. Acyl-homoserine lactone-mediated cross talk among epiphytic bacteria modulates behavior of Pseudomonas syringae on leaves. ISME J. 2009, 3, 825-834. [CrossRef] [PubMed] 
242. Quiñones, B.; Pujol, C.J.; Lindow, S.E. Regulation of AHL Production and Its Contribution to Epiphytic Fitness in Pseudomonas syringae. Mol. Plant Microbe Interact. 2004, 17, 521-531. [CrossRef]

243. Rasmussen, T.B.; Bjarnsholt, T.; Skindersoe, M.E.; Hentzer, M.; Kristoffersen, P.; Köte, M.; Nielsen, J.; Eberl, L.; Givskov, M. Screening for Quorum-Sensing Inhibitors (QSI) by Use of a Novel Genetic System, the QSI Selector. J. Bacteriol. 2005, 187, 1799-1814. [CrossRef]

244. Bjarnsholt, T.; Jensen, P.Ø.; Burmølle, M.; Hentzer, M.; Haagensen, J.A.; Hougen, H.P.; Calum, H.; Madsen, K.G.; Moser, C.; Molin, S.; et al. Pseudomonas Aeruginosa Tolerance to Tobramycin, Hydrogen Peroxide and Polymorphonuclear Leukocytes Is Quorum-Sensing Dependent. Microbiology 2005, 151, 373-383. [CrossRef] [PubMed]

245. Smyth, A.R.; Cifelli, P.M.; Ortori, C.A.; Righetti, K.; Lewis, S.; Erskine, P.; Holland, E.D.; Givskov, M.; Williams, P.; Cámara, M.; et al. Garlic as an inhibitor of Pseudomonas aeruginosa quorum sensing in cystic fibrosis-a pilot randomized controlled trial. Pediatr. Pulmonol. 2010, 45, 356-362. [CrossRef] [PubMed]

246. Hentzer, M.; Wu, H.; Andersen, J.B.; Riedel, K.; Rasmussen, T.B.; Bagge, N.; Kumar, N.; Schembri, M.; Song, Z.; Kristoffersen, P.; et al. Attenuation of Pseudomonas aeruginosa virulence by quorum sensing inhibitors. EMBO J. 2003, 22, 3803-3815. [CrossRef] [PubMed]

247. Fuqua, C.; Winans, S.C.; Greenberg, E.P. Census and Consensus in Bacterial Ecosystems: The Luxr-Luxi Family of Quorum-Sensing Transcriptional Regulators. Annu. Rev. of Microbiol. 1996, 50, 727-751. [CrossRef] [PubMed]

248. Lindum, P.W.; Anthoni, U.; Christophersen, C.; Eberl, L.; Molin, S.; Givskov, M. N-Acyl-1-Homoserine Lactone Autoinducers Control Production of an Extracellular Lipopeptide Biosurfactant Required for Swarming Motility of Serratia liquefaciens MG1. J. Bacteriol. 1998, 180, 6384-6388. [CrossRef]

249. McClean, K.H.; Winson, M.K.; Fish, L.; Taylor, A.; Chhabra, S.R.; Camara, M.; Daykin, M.; Lamb, J.H.; Swift, S.; Bycroft, B.W.; et al. Quorum sensing and Chromobacterium violaceum: Exploitation of violacein production and inhibition for the detection of N-acylhomoserine lactones. Microbiology 1997, 143, 3703-3711. [CrossRef]

250. Shaw, P.D.; Ping, G.; Daly, S.L.; Cha, C.; Cronan, J.E.; Rinehart, K.L.; Farrand, S.K. Detecting and characterizing N-acyl-homoserine lactone signal molecules by thin-layer chromatography. Proc. Natl. Acad. Sci. USA 1997, 94, 6036-6041. [CrossRef]

251. Steidle, A.; Sigl, K.; Schuhegger, R.; Ihring, A.; Schmid, M.; Gantner, S.; Stoffels, M.; Riedel, K.; Givskov, M.; Hartmann, A.; et al. Visualization of N-Acylhomoserine Lactone-Mediated Cell-Cell Communication between Bacteria Colonizing the Tomato Rhizosphere. Appl. Environ. Microbiol. 2001, 67, 5761-5770. [CrossRef]

252. Winson, M.K.; Swift, S.; Fish, L.; Throup, J.P.; Jørgensen, F.; Chhabra, S.R.; Bycroft, B.W.; Williams, P.; Stewart, G.S.A.B. Construction and Analysis of Luxcdabe-Based Plasmid Sensors for Investigating N-Acyl Homoserine Lactone-Mediated Quorum Sensing. FEMS Microbiol. Lett. 1998, 163, 185-192. [CrossRef]

253. Wood, D.W.; Gong, F.; Daykin, M.M.; Williams, P.; Pierson, L.S. N-acyl-homoserine lactone-mediated regulation of phenazine gene expression by Pseudomonas aureofaciens 30-84 in the wheat rhizosphere. J. Bacteriol. 1997, 179, 7663-7670. [CrossRef]

254. Weiland-Bräuer, N.; Pinnow, N.; Schmitz, R.A. Novel Reporter for Identification of Interference with Acyl Homoserine Lactone and Autoinducer-2 Quorum Sensing. Appl. Environ. Microbiol. 2014, 81, 1477-1489. [CrossRef] [PubMed]

255. Cao, J.G.; Meighen, E.A. Biosynthesis and stereochemistry of the autoinducer controlling luminescence in Vibrio harveyi. J. Bacteriol. 1993, 175, 3856-3862. [CrossRef] [PubMed]

256. Tang, K.; Zhang, Y.; Yu, M.; Shi, X.; Coenye, T.; Bossier, P.; Zhang, X.-H. Evaluation of a new high-throughput method for identifying quorum quenching bacteria. Sci. Rep. 2013, 3, 2935. [CrossRef]

257. Weiland-Bräuer, N.; Schmitz, R.A. Quenching Bacterial Communication: Innovative Strategies for Biofilm Inhibition. In Antimicrobial Research: Novel Bioknowledge and Educational Programs; Méndez-Vilas, A., Ed.; Formatex Research Center: Badajoz, Spain, 2017.

258. Muh, U.; Hare, B.J.; Duerkop, B.A.; Schuster, M.; Hanzelka, B.L.; Heim, R.; Olson, E.R.; Greenberg, E. A structurally unrelated mimic of a Pseudomonas aeruginosa acyl-homoserine lactone quorum-sensing signal. Proc. Natl. Acad. Sci. USA 2006, 103, 16948-16952. [CrossRef]

259. Lyon, G.J.; Muir, T.W. Chemical Signaling among Bacteria and Its Inhibition. Chem. Biol. 2003, 10, 1007-1021. [CrossRef] [PubMed]

260. Surette, M.G.; Miller, M.B.; Bassler, B.L. Quorum sensing in Escherichia coli, Salmonella typhimurium, and Vibrio harveyi: A new family of genes responsible for autoinducer production. Proc. Natl. Acad. Sci. USA 1999, 96, 1639-1644. [CrossRef] [PubMed]

261. Rasmussen, T.B.; Givskov, M. Quorum-sensing inhibitors as anti-pathogenic drugs. Int. J. Med. Microbiol. 2006, $296,149-161$. [CrossRef] [PubMed]

262. Romero, M.; Acuña, L.; Otero, A. Patents on Quorum Quenching: Interfering with Bacterial Communication as a Strategy to Fight Infections. Recent Patents Biotechnol. 2012, 6, 2-12. [CrossRef]

263. Lade, H.; Paul, D.; Kweon, J.H. Quorum Quenching Mediated Approaches for Control of Membrane Biofouling. Int. J. Biol. Sci. 2014, 10, 550-565. [CrossRef]

264. Romero, M.; Martin-Cuadrado, A.-B.; Roca-Rivada, A.; Cabello, A.M.; Otero, A. Quorum quenching in cultivable bacteria from dense marine coastal microbial communities. FEMS Microbiol. Ecol. 2010, 75, 205-217. [CrossRef]

265. Krzyżek, P. Challenges and Limitations of Anti-quorum Sensing Therapies. Front. Microbiol. 2019, 10, 2473. [CrossRef]

266. Defoirdt, T.; Boon, N.; Bossier, P. Can Bacteria Evolve Resistance to Quorum Sensing Disruption? PLoS Pathog. 2010, 6, e1000989. [CrossRef] 
267. Maeda, T.; García-Contreras, R.; Pu, M.; Sheng, L.; Garcia, L.R.; Tomás, M.; Wood, T.K. Quorum quenching quandary: Resistance to antivirulence compounds. ISME J. 2011, 6, 493-501. [CrossRef] [PubMed]

268. Margulis, L. Symbiosis in Cell Evolution: Life and Its Environment on the Early Earth; NASA Technical Reports Server (NTRS): Washington, DC, USA, 1981.

269. Margulis, L. Biodiversity: Molecular biological domains, symbiosis and kingdom origins. Biosystems 1992, 27, 39-51. [CrossRef]

270. Margulis, L. Archaeal-eubacterial mergers in the origin of Eukarya: Phylogenetic classification of life. Proc. Natl. Acad. Sci. USA 1996, 93, 1071-1076. [CrossRef] [PubMed]

271. Margulis, L.; Chapman, M.J. Kingdoms and Domains: An. Illustrated Guide to the Phyla of Life on Earth; Academic Press: Cambridge, MA, USA, 2009.

272. Rosenberg, E.; Zilber-Rosenberg, I. The Hologenome Concept. In Beneficial Microorganisms in Multicellular Life Forms; Metzler, J.B., Ed.; Springer: Berlin, Germany, 2012; pp. 323-340.

273. The Hologenome Concept: Human, Animal and Plant. In Microbiota; Springer: Berlin/Heidelberg, Germany, 2014.

274. Rosenberg, E.; Zilber-Rosenberg, I. Symbiosis and development: The hologenome concept. Birth Defects Res. Part. C Embryo Today Rev. 2011, 93, 56-66. [CrossRef] [PubMed]

275. Bosch, T.C.; McFall-Ngai, M.J. Metaorganisms as the new frontier. Zoölogy 2011, 114, 185-190. [CrossRef] [PubMed]

276. Jaspers, C.; Fraune, S.; Arnold, A.E.; Miller, D.J.; Bosch, T.C.; Voolstra, C.R. Resolving structure and function of metaorganisms through a holistic framework combining reductionist and integrative approaches. Zoölogy 2019, 133, 81-87. [CrossRef] [PubMed]

277. Boon, E.; Meehan, C.J.; Whidden, C.; Wong, D.H.-J.; Langille, M.G.; Beiko, R.G. Interactions in the microbiome: Communities of organisms and communities of genes. FEMS Microbiol. Rev. 2014, 38, 90-118. [CrossRef]

278. Bang, C.; Dagan, T.; Deines, P.; Dubilier, N.; Duschl, W.J.; Fraune, S.; Hentschel, U.; Hirt, H.; Hülter, N.F.; Lachnit, T.; et al. Metaorganisms in extreme environments: Do microbes play a role in organismal adaptation? Zoölogy 2018, 127, 1-19. [CrossRef]

279. Rosenberg, E.; Zilber-Rosenberg, I. The hologenome concept of evolution after 10 years. Microbiome 2018, 6, 1-14. [CrossRef]

280. Leitz, T.; Wagner, T. The marine bacterium Alteromonas espejiana induces metamorphosis of the hydroid Hydractinia echinata. Mar. Biol. 1993, 115, 173-178. [CrossRef]

281. Unabia, C.R.C.; Hadfield, M. Role of bacteria in larval settlement and metamorphosis of the polychaete Hydroides elegans. Mar Biol. 1999, 133, 55-64. [CrossRef]

282. Woznica, A.; Gerdt, J.; Hulett, R.E.; Clardy, J.; King, N. Mating in the Closest Living Relatives of Animals Is Induced by a Bacterial Chondroitinase. Cell 2017, 170, 1175-1183. [CrossRef] [PubMed]

283. Webster, N.S.; Smith, L.D.; Heyward, A.J.; Watts, J.E.M.; Webb, R.I.; Blackall, L.L.; Negri, A.P. Metamorphosis of a Scleractinian Coral in Response to Microbial Biofilms. Appl. Environ. Microbiol. 2004, 70, 1213-1221. [CrossRef] [PubMed]

284. Fraune, S.; Anton-Erxleben, F.; Augustin, R.; Franzenburg, S.; Knop, M.; Schröder, K.; Willoweit-Ohl, D.; Bosch, T.C.G. Bacteriabacteria interactions within the microbiota of the ancestral metazoan Hydra contribute to fungal resistance. ISME J. 2015, 9, 1543-1556. [CrossRef]

285. Moran, N.A.; Yun, Y. Experimental replacement of an obligate insect symbiont. Proc. Natl. Acad. Sci. USA 2015, 112, 2093-2096. [CrossRef] [PubMed]

286. Roder, C.; Bayer, T.; Aranda, M.; Kruse, M.; Voolstra, C.R. Microbiome Structure of the Fungid Coral Ctenactis Echinata Aligns with Environmental Differences. Mol. Ecol. 2015, 24, 3501-3511. [CrossRef]

287. Hume, B.C.C.; Voolstra, C.R.; Arif, C.; D’Angelo, C.; Burt, J.A.; Eyal, G.; Loya, Y.; Wiedenmann, J. Ancestral Genetic Diversity Associated with the Rapid Spread of Stress-Tolerant Coral Symbionts in Response to Holocene Climate Change. Proc. Natl. Acad. Sci. USA 2016, 113, 4416-4421. [CrossRef]

288. Mortzfeld, B.M.; Urbanski, S.; Reitzel, A.M.; KÃ $\frac{1}{4}$ nzel, S.; Technau, U.; Fraune, S. Response of Bacterial Colonization in Nematostella Vectensis to Development, Environment and Biogeography. Environ. Microbiol. 2016, 18, 1764-1781. [CrossRef]

289. Röthig, T.; Costa, R.M.; Simona, F.; Baumgarten, S.; Torres, A.F.; Radhakrishnan, A.; Aranda, M.; Voolstra, C.R. Distinct Bacterial Communities Associated with the Coral Model Aiptasia in Aposymbiotic and Symbiotic States with Symbiodinium. Front. Mar. Sci. 2016, 3. [CrossRef]

290. Araldi-Brondolo, S.J.; Spraker, J.; Shaffer, J.P.; Woytenko, E.H.; Baltrus, D.A.; Gallery, R.E.; Arnold, A.E. Bacterial Endosymbionts: Master Modulators of Fungal Phenotypes. Fungal Kingd. 2017, 981-1004.

291. Ochsenkühn, M.A.; Röthig, T.; D’Angelo, C.; Wiedenmann, J.; Voolstra, C.R. The role of floridoside in osmoadaptation of coral-associated algal endosymbionts to high-salinity conditions. Sci. Adv. 2017, 3, e1602047. [CrossRef] [PubMed]

292. Shaffer, J.P.; U'Ren, J.M.; Gallery, R.E.; Baltrus, D.A.; Arnold, A.E. An Endohyphal Bacterium (Chitinophaga, Bacteroidetes) Alters Carbon Source Use by Fusarium keratoplasticum (F. solani Species Complex, Nectriaceae). Front. Microbiol. 2017, 8, 350. [CrossRef] [PubMed]

293. Ziegler, M.; Seneca, F.; Yum, L.K.; Palumbi, S.R.; Voolstra, C.R. Bacterial community dynamics are linked to patterns of coral heat tolerance. Nat. Commun. 2017, 8, 14213. [CrossRef] [PubMed]

294. Rook, G.; Bäckhed, F.; Levin, B.R.; McFall-Ngai, M.J.; McLean, A.R. Evolution, human-microbe interactions, and life history plasticity. Lancet 2017, 390, 521-530. [CrossRef]

295. Esser, D.; Lange, J.; Marinos, G.; Sieber, M.; Best, L.; Prasse, D.; Bathia, J.; Rühlemann, M.; Boersch, K.; Jaspers, C.; et al. Functions of the Microbiota for the Physiology of Animal Metaorganisms. J. Innate Immun. 2019, 11, 393-404. [CrossRef] 
296. Mills, E.; Shechtman, K.; Loya, Y.; Rosenberg, E. Bacteria appear to play important roles in both causing and preventing the bleaching of the coral Oculina patagonica. Mar. Ecol. Prog. Ser. 2013, 489, 155-162. [CrossRef]

297. Krediet, C.J.; Ritchie, K.B.; Alagely, A.; Teplitski, M. Members of native coral microbiota inhibit glycosidases and thwart colonization of coral mucus by an opportunistic pathogen. ISME J. 2012, 7, 980-990. [CrossRef]

298. Formal, S.B.; Dammin, G.; Sprinz, H.; Kundel, D.; Schneider, H.; Horowitz, R.E.; Forbes, M. Experimental Shigella infections. V. Studies in germ-free guinea pigs. J. Bacteriol. 1961, 82, 284-287. [CrossRef]

299. Butterton, J.R.; Ryan, E.T.; Shahin, R.A.; Calderwood, S.B. Development of a Germfree Mouse Model of Vibrio Cholerae Infection. Infect. Immun. 1996, 64, 4373-4377. [CrossRef]

300. Shanmugam, M.; Sethupathi, P.; Rhee, K.-J.; Yong, S.; Knight, K.L. Bacterial-induced Inflammation in Germ-free Rabbit Appendix. Inflamm. Bowel Dis. 2005, 11, 992-996. [CrossRef] [PubMed]

301. Huppert, M.; MacPherson, D.A.; Cazin, J. Pathogenesis of Candida Albicans Infection following Antibiotic Therapy I. J. Bacteriol. 1953, 65, 171-176. [CrossRef] [PubMed]

302. Witkin, S.S.; Mendes-Soares, H.; Linhares, I.M.; Jayaram, A.; Ledger, W.J.; Forney, L.J. Influence of Vaginal Bacteria and d- and 1-Lactic Acid Isomers on Vaginal Extracellular Matrix Metalloproteinase Inducer: Implications for Protection against Upper Genital Tract Infections. mBio 2013, 4, e00874-14. [CrossRef] [PubMed]

303. Guarino, A.; Vecchio, A.L.; Canani, R.B. Probiotics as prevention and treatment for diarrhea. Curr. Opin. Gastroenterol. 2009, 25, 18-23. [CrossRef] [PubMed]

304. Sela, D.A.; Chapman, J.; Adeuya, A.; Kim, J.H.; Chen, F.; Whitehead, T.R.; Lapidus, A.; Rokhsar, D.; Lebrilla, C.B.; German, J.B.; et al. The genome sequence of Bifidobacterium longum subsp. infantis reveals adaptations for milk utilization within the infant microbiome. Proc. Natl. Acad. Sci. USA 2008, 105, 18964-18969. [CrossRef] [PubMed]

305. Innerebner, G.; Knief, C.; Vorholt, J.A. Protection of Arabidopsis thaliana against Leaf-Pathogenic Pseudomonas syringae by Sphingomonas Strains in a Controlled Model System. Appl. Environ. Microbiol. 2011, 77, 3202-3210. [CrossRef]

306. Cytryn, E.; Kolton, M. Microbial Protection Against Plant Disease. In Beneficial Microorganisms in Multicellular Life Forms; Metzler, J.B., Ed.; Springer: Berlin, Germany, 2012; pp. 123-136.

307. Vishwakarma, K.; Kumar, N.; Shandilya, C.; Mohapatra, S.; Bhayana, S.; Varma, A. Revisiting Plant-Microbe Interactions and Microbial Consortia Application for Enhancing Sustainable Agriculture: A Review. Front. Microbiol. 2020, 11, 3195. [CrossRef] [PubMed]

308. Kowalchuk, G.A.; Buma, D.S.; De Boer, W.; Klinkhamer, P.G.L.; Van Veen, J.A. Effects of above-ground plant species composition and diversity on the diversity of soil-borne microorganisms. Antonie van Leeuwenhoek 2002, 81, 509-520. [CrossRef] [PubMed]

309. Van Der Putten, W.H.; Bardgett, R.D.; Bever, J.D.; Bezemer, T.M.; Casper, B.B.; Fukami, T.; Kardol, P.; Klironomos, J.N.; Kulmatiski, A.; Schweitzer, J.A.; et al. Plant-soil feedbacks: The past, the present and future challenges. J. Ecol. 2013, 101, 265-276. [CrossRef]

310. Hill, P.W.; Jones, D.L. Plant-microbe competition: Does injection of isotopes of $C$ and $N$ into the rhizosphere effectively characterise plant use of soil N? New Phytol. 2018, 221, 796-806. [CrossRef]

311. Alori, E.T.; Dare, M.O.; Babalola, O.O. Microbial Inoculants for Soil Quality and Plant Health. Sustain. Agric. Rev. 2017, 281-307, 281-307. [CrossRef]

312. Majeed, A.; Muhammad, Z.; Ahmad, H. Plant growth promoting bacteria: Role in soil improvement, abiotic and biotic stress management of crops. Plant. Cell Rep. 2018, 37, 1599-1609. [CrossRef] [PubMed]

313. Dubilier, N.; Bergin, C.; Lott, C. Symbiotic diversity in marine animals: The art of harnessing chemosynthesis. Nat. Rev. Genet. 2008, 6, 725-740. [CrossRef] [PubMed]

314. Childress, J.J.; Girguis, P. The metabolic demands of endosymbiotic chemoautotrophic metabolism on host physiological capacities. J. Exp. Biol. 2011, 214, 312-325. [CrossRef]

315. Sekirov, I.; Russell, S.L.; Antunes, L.C.M.; Finlay, B.B. Gut Microbiota in Health and Disease. Physiol. Rev. 2010, 90, 859-904. [CrossRef] [PubMed]

316. Rajilic-Stojanovic, M.; Figueiredo, C.; Smet, A.; Hansen, R.; Kupcinskas, J.; Rokkas, T.; Andersen, L.; Machado, J.C.; Ianiro, G.; Gasbarrini, A.; et al. Systematic review: Gastric microbiota in health and disease. Aliment. Pharmacol. Ther. 2020, 51, 582-602. [CrossRef]

317. Heijtz, R.D. The Microbiome: Interactions with Organ. Systems, Diet., and Genetics, An Issue of Gastroenterology Clinics of North America, Ebook; Elsevier: Amsterdam, The Netherlands, 2019.

318. Provasoli, L.; Pintner, I.J. Bacteria Induced Polymorphism in an Axenic Laboratory Strain of Ulva Lactuca (Chlorophyceae) 1. J. Phycol. 1980, 16, 196-201. [CrossRef]

319. Ewichard, T. Exploring bacteria-induced growth and morphogenesis in the green macroalga order Ulvales (Chlorophyta). Front. Plant. Sci. 2015, 6, 86. [CrossRef] [PubMed]

320. Round, L.J.; Mazmanian, S.K. The Gut Microbiota Shapes Intestinal Immune Responses during Health and Disease. Nat. Rev. Immunol. 2009, 9, 313-323. [CrossRef]

321. Sun, J.; Dudeja, P.K. Mechanisms Underlying Host-Microbiome Interactions in Pathophysiology of Human Diseases; Springer: Berlin/Heidelberg, Germany, 2018.

322. Heijtz, R.D.; Wang, S.; Anuar, F.; Qian, Y.; Björkholm, B.; Samuelsson, A.; Hibberd, M.L.; Forssberg, H.; Pettersson, S. Normal gut microbiota modulates brain development and behavior. Proc. Natl. Acad. Sci. USA 2011, 108, 3047-3052. [CrossRef] [PubMed] 
323. Bravo, J.A.; Forsythe, P.; Chew, M.V.; Escaravage, E.; Savignac, H.M.; Dinan, T.G.; Bienenstock, J.; Cryan, J.F. Ingestion of Lactobacillus strain regulates emotional behavior and central GABA receptor expression in a mouse via the vagus nerve. Proc. Natl. Acad. Sci. USA 2011, 108, 16050-16055. [CrossRef] [PubMed]

324. Shaw, W. Increased Urinary Excretion of a 3-(3-Hydroxyphenyl)-3-Hydroxypropionic Acid (Hphpa), an Abnormal Phenylalanine Metabolite of Clostridia Spp. In the Gastrointestinal Tract, in Urine Samples from Patients with Autism and Schizophrenia. Nutr. Neurosci. 2010, 13, 135-143. [CrossRef]

325. Huang, T.-T.; Lai, J.-B.; Du, Y.-L.; Xu, Y.; Ruan, L.-M.; Hu, S.-H. Current Understanding of Gut Microbiota in Mood Disorders: An Update of Human Studies. Front. Genet. 2019, 10, 98. [CrossRef]

326. Mörkl, S.; Butler, M.I.; Holl, A.; Cryan, J.F.; Dinan, T.G. Probiotics and the Microbiota-Gut-Brain Axis: Focus on Psychiatry. Curr Nutr. Rep. 2020, 9, 171-182. [CrossRef]

327. Ben-Dov, E.; Kramarsky-Winter, E.; Kushmaro, A. An in situ method for cultivating microorganisms using a double encapsulation technique. FEMS Microbiol. Ecol. 2009, 68, 363-371. [CrossRef]

328. Backhed, F.; Ley, R.E.; Sonnenburg, J.L.; Peterson, D.A.; Gordon, J.I. Host-Bacterial Mutualism in the Human Intestine. Science 2005, 307, 1915-1920. [CrossRef]

329. Douglas, A.E. Conflict, cheats and the persistence of symbioses. New Phytol. 2008, 177, 849-858. [CrossRef] [PubMed]

330. Rowland, I.; Gibson, G.; Heinken, A.; Scott, K.; Swann, J.; Thiele, I.; Tuohy, K. Gut microbiota functions: Metabolism of nutrients and other food components. Eur. J. Nutr. 2018, 57, 1-24. [CrossRef] [PubMed]

331. Feng, H.; Edwards, N.; Anderson, C.M.H.; Althaus, M.; Duncan, R.P.; Hsu, Y.; Luetje, C.W.; Price, D.R.G.; Wilson, A.C.C.; Thwaites, D.T. Trading Amino Acids at the Aphid-Buchnera Symbiotic Interface. Proc. Natl. Acad. Sci. USA 2019, 116, 16003. [CrossRef] [PubMed]

332. Shigenobu, S.; Wilson, A.C.C. Genomic Revelations of a Mutualism: The Pea Aphid and Its Obligate Bacterial Symbiont. Cell. Mol. Life Sci. CMLS 2011, 68, 1297-1309. [CrossRef] [PubMed]

333. Redecker, D.; Kodner, R.; Graham, L.E. Palaeoglonius Grayi from the Ordovician. Mycotaxon 2002, 84, $33-37$.

334. Feijen, F.A.A.; Vos, R.; Nuytinck, J.; Merckx, V.S.F.T. Evolutionary dynamics of mycorrhizal symbiosis in land plant diversification. Sci. Rep. 2018, 8, 1-7. [CrossRef] [PubMed]

335. Wood, P.R.; Wood, R. Reef Evolution; Oxford University Press: New York, NY, USA, 1999.

336. Collinson, M.E.; Hooker, J.J.; Skelton, P.W.; Moore, P.D.; Ollerton, J.; Alexander, R.M. Fossil evidence of interactions between plants and plant-eating mammals. Philos. Trans. R. Soc. B Biol. Sci. 1991, 333, 197-208. [CrossRef]

337. Ochman, H.; Worobey, M.; Kuo, C.-H.; Ndjango, J.-B.N.; Peeters, M.; Hahn, B.H.; Hugenholtz, P. Evolutionary Relationships of Wild Hominids Recapitulated by Gut Microbial Communities. PLoS Biol. 2010, 8, e1000546. [CrossRef]

338. Yildirim, S.; Yeoman, C.J.; Sipos, M.; Torralba, M.; Wilson, B.A.; Goldberg, T.L.; Stumpf, R.M.; Leigh, S.R.; White, B.A.; Nelson, K.E. Characterization of the Fecal Microbiome from Non-Human Wild Primates Reveals Species Specific Microbial Communities. PLoS ONE 2010, 5, e13963. [CrossRef]

339. Jami, E.; Israel, A.; Kotser, A.; Mizrahi, I. Exploring the bovine rumen bacterial community from birth to adulthood. ISME J. 2013, 7, 1069-1079. [CrossRef]

340. Brune, A. Symbiotic digestion of lignocellulose in termite guts. Nat. Rev. Genet. 2014, 12, 168-180. [CrossRef]

341. Kikuchi, Y.; Masahito, H.; Hosokawa, T.; Nagayama, A.; Tago, K.; Fukatsu, T. Symbiont-Mediated Insecticide Resistane. Proc. Natl. Acad. Sci. USA 2012, 109, 8618-8622. [CrossRef]

342. Keeling, P.J.; Palmer, J.D. Horizontal gene transfer in eukaryotic evolution. Nat. Rev. Genet. 2008, 9, 605-618. [CrossRef] [PubMed]

343. Moran, N.A.; Jarvik, T. Lateral Transfer of Genes from Fungi Underlies Carotenoid Production in Aphids. Science 2010, 328, 624-627. [CrossRef] [PubMed]

344. Hotopp, J.C.D.; Clark, M.E.; Oliveira, D.C.S.G.; Foster, J.M.; Fischer, P.; Torres, M.C.M.; Giebel, J.D.; Kumar, N.; Ishmael, N.; Wang, S.; et al. Widespread Lateral Gene Transfer from Intracellular Bacteria to Multicellular Eukaryotes. Science 2007, 317, 1753-1756. [CrossRef] [PubMed]

345. Anderson, M.T.; Seifert, H.S. Opportunity and Means: Horizontal Gene Transfer from the Human Host to a Bacterial Pathogen. mBio 2010, 2, e00005-11. [CrossRef]

346. Liu, J.; Meng, Z.; Liu, X.; Zhang, X.-H. Microbial assembly, interaction, functioning, activity and diversification: A review derived from community compositional data. Mar. Life Sci. Technol. 2019, 1, 112-128. [CrossRef]

347. Fakruddin, M.; Mannan, K. Methods for Analyzing Diversity of Microbial Communities in Natural Environments. Ceylon J. Sci. Biol. Sci. 2013, 42, 19-33. [CrossRef]

348. Handelsman, J.; Rondon, M.R.; Brady, S.F.; Clardy, J.; Goodman, R.M. Molecular biological access to the chemistry of unknown soil microbes: A new frontier for natural products. Chem. Biol. 1998, 5, R245-R249. [CrossRef]

349. Handelsman, J. Metagenomics: Application of Genomics to Uncultured Microorganisms. Microbiol. Mol. Biol. Rev. 2004, 68, 669-685. [CrossRef] [PubMed]

350. Weiland-Bräuer, N.; Langfeldt, D.; Schmitz, R.A. Construction and Screening of Marine Metagenomic Large Insert Libraries. Methods Mol. Biol. 2016, 1539, 23-42. [CrossRef]

351. Craig, J.W. The Application of Functional Metagenomics to Natural Products Research. Ph.D. Thesis, The Rockefeller University, New York, NY, USA, 2012. 
352. Chistoserdova, L. Recent progress and new challenges in metagenomics for biotechnology. Biotechnol. Lett. 2010, 32, 1351-1359. [CrossRef] [PubMed]

353. Chistoserdovai, L. Functional metagenomics: Recent advances and future challenges. Biotechnol. Genet. Eng. Rev. 2010, 26, 335-352. [CrossRef] [PubMed]

354. Steele, H.L.; Jaeger, K.-E.; Daniel, R.; Streit, W.R. Advances in Recovery of Novel Biocatalysts from Metagenomes. J. Mol. Microbiol. Biotechnol. 2009, 16, 25-37. [CrossRef] [PubMed]

355. Council, N.R. The New Science of Metagenomics: Revealing the Secrets of Our Microbial Planet; The National Academies Press: Washington, DC, USA, 2007.

356. Ngara, T.R.; Zhang, H. Recent Advances in Function-based Metagenomic Screening. Genom. Proteom. Bioinform. 2018, 16, 405-415. [CrossRef] [PubMed]

357. Riesenfeld, C.S.; Schloss, P.; Handelsman, J. Metagenomics: Genomic Analysis of Microbial Communities. Annu. Rev. Genet. 2004, 38, 525-552. [CrossRef]

358. Streit, W.R.; Schmitz, R.A. Metagenomics-The Key to the Uncultured Microbes. Curr. Opin. Microbiol. 2004, 7, $492-498$. [CrossRef] [PubMed]

359. Tringe, S.G.; Rubin, E.M. Metagenomics: DNA Sequencing of Environmental Samples. Nat. Rev. Genet. 2005, 6, 805-814. [CrossRef] [PubMed]

360. Ferrer, M.; Martinez-Abarca, F.; Golyshin, P.N. Mining Genomes and 'Metagenomes' for Novel Catalysts. Curr. Opin. Biotechnol. 2005, 16, 588-593. [CrossRef]

361. Tringe, S.G.; von Mering, C.; Kobayashi, A.; Salamov, A.A.; Chen, K.; Chang, H.W.; Podar, M.; Short, J.M.; Mathur, E.J.; Detter, J.C.; et al. Comparative Metagenomics of Microbial Communities. Science 2005, 308, 554-557. [CrossRef] [PubMed]

362. Petrosino, J.F.; Highlander, S.; Luna, R.A.; Gibbs, R.A.; Versalovic, J. Metagenomic Pyrosequencing and Microbial Identification. Clin. Chem. 2009, 55, 856-866. [CrossRef] [PubMed]

363. Schmeisser, C.; Steele, H.; Streit, W.R. Metagenomics, biotechnology with non-culturable microbes. Appl. Microbiol. Biotechnol. 2007, 75, 955-962. [CrossRef]

364. Piel, J. Metabolites from symbiotic bacteriaThis review is dedicated to Professor Axel Zeeck on the occasion of his 65th birthday. Nat. Prod. Rep. 2004, 21, 519-538. [CrossRef] [PubMed]

365. Gillespie, D.E.; Brady, S.F.; Bettermann, A.D.; Cianciotto, N.P.; Liles, M.R.; Rondon, M.R.; Clardy, J.; Goodman, R.M.; Handelsman, J. Isolation of Antibiotics Turbomycin A and B from a Metagenomic Library of Soil Microbial DNA. Appl. Environ. Microbiol. 2002, 68, 4301-4306. [CrossRef] [PubMed]

366. Brady, S.F.; Clardy, J. Palmitoylputrescine, an Antibiotic Isolated from the Heterologous Expression of DNA Extracted from Bromeliad Tank Water. J. Nat. Prod. 2004, 67, 1283-1286. [CrossRef]

367. Eyers, L.; George, I.; Schuler, L.; Stenuit, B.; Agathos, S.N.; El Fantroussi, S. Environmental genomics: Exploring the unmined richness of microbes to degrade xenobiotics. Appl. Microbiol. Biotechnol. 2004, 66, 123-130. [CrossRef] [PubMed]

368. Voget, S.; Steele, H.; Streit, W. Characterization of a metagenome-derived halotolerant cellulase. J. Biotechnol. 2006, 126, 26-36. [CrossRef]

369. Gabor, E.M.; Alkema, W.; Janssen, D.B. Quantifying the accessibility of the metagenome by random expression cloning techniques. Environ. Microbiol. 2004, 6, 879-886. [CrossRef] [PubMed]

370. Knietsch, A.; Waschkowitz, T.; Bowien, S.; Henne, A.; Daniel, R. Construction and Screening of Metagenomic Libraries Derived from Enrichment Cultures: Generation of a Gene Bank for Genes Conferring Alcohol Oxidoreductase Activity on Escherichia coli. Appl. Environ. Microbiol. 2003, 69, 1408-1416. [CrossRef]

371. Lee, S.-W.; Won, K.; Lim, H.K.; Kim, J.-C.; Choi, G.J.; Cho, K.Y. Screening for novel lipolytic enzymes from uncultured soil microorganisms. Appl. Microbiol. Biotechnol. 2004, 65, 720-726. [CrossRef]

372. Liebeton, K.; Eck, J. Identification and Expression in E. coli of Novel Nitrile Hydratases from the Metagenome. Eng. Life Sci. 2004, 4, 557-562. [CrossRef]

373. Rhee, J.-K.; Ahn, D.-G.; Kim, Y.-G.; Oh, J.-W. New Thermophilic and Thermostable Esterase with Sequence Similarity to the Hormone-Sensitive Lipase Family, Cloned from a Metagenomic Library. Appl. Environ. Microbiol. 2005, 71, 817-825. [CrossRef] [PubMed]

374. Yun, J.; Kang, S.; Park, S.; Yoon, H.; Kim, M.-J.; Heu, S.; Ryu, S. Characterization of a Novel Amylolytic Enzyme Encoded by a Gene from a Soil-Derived Metagenomic Library. Appl. Environ. Microbiol. 2004, 70, 7229-7235. [CrossRef]

375. de Fátima Alves, L.; Westmann, C.A.; Lovate, G.L.; de Siqueira, G.M.V.; Borelli, T.C.; Guazzaroni, M. Metagenomic Approaches for Understanding New Concepts in Microbial Science. Int. J. Genom. 2018, 2018, 2312987.

376. Bashiardes, S.; Zilberman-Schapira, G.; Elinav, E. Use of Metatranscriptomics in Microbiome Research. Bioinform. Biol. Insights 2016, 10, BBI.S34610-25. [CrossRef] [PubMed]

377. Nawy, T. Capturing microbial interactions. Nat. Chem. Biol. 2017, 14, 35. [CrossRef]

378. Earle, K.A.; Billings, G.; Sigal, M.; Lichtman, J.S.; Hansson, G.C.; Elias, J.E.; Amieva, M.R.; Huang, K.C.; Sonnenburg, J.L. Quantitative Imaging of Gut Microbiota Spatial Organization. Cell Host Microbe 2015, 18, 478-488. [CrossRef]

379. Geva-Zatorsky, N.; Alvarez, D.; Hudak, J.E.; Reading, N.C.; Erturk-Hasdemir, D.; Dasgupta, S.; Von Andrian, U.H.; Kasper, D.L. In vivo imaging and tracking of host-microbiota interactions via metabolic labeling of gut anaerobic bacteria. Nat. Med. 2015, 21, 1091-1100. [CrossRef] 
380. Haruta, S.; Yamamoto, K. Model Microbial Consortia as Tools for Understanding Complex Microbial Communities. Curr. Genom. 2018, 19, 723-733. [CrossRef]

381. Zuñiga, C.; Zaramela, L.; Zengler, K. Elucidation of complexity and prediction of interactions in microbial communities. Microb. Biotechnol. 2017, 10, 1500-1522. [CrossRef] [PubMed]

382. Medlock, G.L.; Carey, M.A.; McDuffie, D.G.; Mundy, M.B.; Giallourou, N.; Swann, J.R.; Kolling, G.L.; Papin, J.A. Inferring Metabolic Mechanisms of Interaction within a Defined Gut Microbiota. Cell Syst. 2018, 7, 245-257.e7. [CrossRef]

383. Wang, Y.-H.; Wei, K.Y.; Smolke, C.D. Synthetic Biology: Advancing the Design of Diverse Genetic Systems. Annu. Rev. Chem. Biomol. Eng. 2013, 4, 69-102. [CrossRef]

384. Massalha, H.; Korenblum, E.; Malitsky, S.; Shapiro, O.H.; Aharoni, A. Live imaging of root-bacteria interactions in a microfluidics setup. Proc. Natl. Acad. Sci. USA 2017, 114, 4549-4554. [CrossRef] [PubMed]

385. Lambert, B.S.; Raina, J.-B.; Fernandez, V.I.; Rinke, C.; Siboni, N.; Rubino, F.; Hugenholtz, P.; Tyson, G.W.; Seymour, J.R.; Stocker, R. A microfluidics-based in situ chemotaxis assay to study the behaviour of aquatic microbial communities. Nat. Microbiol. 2017, 2, 1344-1349. [CrossRef] [PubMed]

386. Overmann, J.; Abt, B.; Sikorski, J. Present and Future of Culturing Bacteria. Annu. Rev. Microbiol. 2017, 71, 711-730. [CrossRef] [PubMed]

387. Chijiiwa, R.; Hosokawa, M.; Kogawa, M.; Nishikawa, Y.; Ide, K.; Sakanashi, C.; Takahashi, K.; Takeyama, H. Single-cell genomics of uncultured bacteria reveals dietary fiber responders in the mouse gut microbiota. Microbiome 2020, 8, 1-14. [CrossRef]

388. Domin, H.; Zurita-Gutiérrez, Y.H.; Scotti, M.; Buttlar, J.; Humeida, U.H.; Fraune, S. Predicted Bacterial Interactions Affect in Vivo Microbial Colonization Dynamics in Nematostella. Front. Microbiol. 2018, 9, 728. [CrossRef]

389. Voolstra, C.R. A journey into the wild of the cnidarian model system Aiptasia and its symbionts. Mol. Ecol. 2013, 22, 4366-4368. [CrossRef]

390. Wein, T.; Dagan, T.; Fraune, S.; Bosch, T.C.G.; Reusch, T.B.H.; Hülter, N.F. Carrying Capacity and Colonization Dynamics of Curvibacter in the Hydra Host Habitat. Front. Microbiol. 2018, 9, 443. [CrossRef]

391. Li, X.-Y.; Pietschke, C.; Fraune, S.; Altrock, P.M.; Bosch, T.C.G.; Traulsen, A. Which games are growing bacterial populations playing? J. R. Soc. Interface 2015, 12, 20150121. [CrossRef] [PubMed]

392. Karoline, F.; Raes, J. Microbial Interactions: From Networks to Models. Nat. Rev. Microbiol. 2012, 10, 538.

393. Jiang, L.-L.; Zhou, J.-J.; Quan, C.-S.; Xiu, Z.-L. Advances in industrial microbiome based on microbial consortium for biorefinery. Bioresour. Bioprocess. 2017, 4, 507. [CrossRef] [PubMed]

394. Mccarty, N.S.; Ledesma-Amaro, R. Synthetic biology tools to engineer microbial communities for biotechnology. Trends Biotechnol. 2019, 37, 181-197. [CrossRef]

395. Ghosh, S.; Chowdhury, R.; Bhattacharya, P. Mixed consortia in bioprocesses: Role of microbial interactions. Appl. Microbiol. Biotechnol. 2016, 100, 4283-4295. [CrossRef] [PubMed] 